\title{
Identification from a Combinatorial Library of a Small Molecule that Selectively Induces Apoptosis in Cancer Cells
}

\author{
Vitaliy Nesterenko, Karson S. Putt, and Paul J. Hergenrother*
}

Roger Adams Laboratory, University of Illinois, Urbana IL 61801

hergenro@uiuc.edu

Supporting Information 


\section{Materials and methods.}

${ }^{1} \mathrm{H}$ and ${ }^{13} \mathrm{C}$ NMR spectra were recorded on Varian Unity400 $\left(400 \mathrm{MHz}{ }^{1} \mathrm{H}, 100 \mathrm{MHz}\right.$ ${ }^{13} \mathrm{C}$ ) and on Varian Unity500 $\left(500 \mathrm{MHz}{ }^{1} \mathrm{H}, 125 \mathrm{MHz}{ }^{13} \mathrm{C}\right)$ spectrometers in deuterochloroform $\left(\mathrm{CDCl}_{3}\right)$ or deuteromethanol $\left(\mathrm{CD}_{3} \mathrm{OD}\right)$. The data is reported as follows: chemical shifts in ppm $(\delta)$, multiplicities are indicated as s-singlet; d-doublet; t-triplet; q-quartet; m-multiplet, br - broad. Coupling constants, $J$, are reported in Hz. Infrared spectra were recorded on Perkin Elmer Spectrum BX spectrophotometer, referenced to polystyrene standard, and the peaks reported in $\mathrm{cm}^{-1}$. Mass spectra were recorded by the University of Illinois Mass Spectroscopy Center, and the data reported in $m / e$ (intensity to $100 \%$ ). Analytical thin-layer chromatography was performed on Merk silica gel plated with F254 indicator. The plates were visualized by UV light, Iodine $\left(\mathrm{I}_{2}\right)$ and/or CAM stain. Optical rotations were obtained on Jasco DIP-360 Digital Polarimeter. Analytical chiral supercritical fluid chromatography (SFC) was performed on Berger Instruments SFC equipped with Diacel Chiracel OD column (250 x $4.5 \mathrm{~mm})$, internal spectrophotometric detector operated at wavelength $220 \mathrm{nM}$. Solvents for extraction and chromatography were reagent grade and were used without further purification. Melting points were determined on a Thomas-Hoover Capillary Melting Point Apparatus and are uncorrected. The $\mathrm{pH}$ of solutions was measured by Aquemet ${ }^{\mathrm{TM}}$ Research AR15 pH meter equipped with Corning semimicrocombo electrode (\#476156), which was standardized by 5 buffer solutions $(\mathrm{pH}=4.0 \pm 0.01,6.0 \pm 0.01,7.0 \pm 0.01,9.0 \pm 0.01$ and $10.0 \pm 0.01)$ prior to measurements.

Acids A-G were purchased from Aldrich and used as received. Acid $\mathbf{H}$ was prepared by Wadsworth-Emmons olefination following a procedure described in Organic Synthesis, CV 5, p. 547 from anisaldehyde, which was purchased from Aldrich. PS-carbodiimide resin was purchased from Argonaut Technologies (1101 Chess Dr. Foster City, CA 94404). N-Cbz-1Aryl-2-aminoethanols were prepared by previously reported procedure. ${ }^{1}$ Amines 16, 17, 18 were purchased from Aldrich.

\section{General procedure for asymmetric aminohydroxylation of styrenes}

As described for the synthesis of [(S)-2-hydroxy-2-(4-acetoxy-phenyl)-ethyl]-carbamic acid benzyl ester (5):

In a $1000 \mathrm{~mL}$ round bottom three-neck flask, under an atmosphere of $\mathrm{N}_{2}$, benzyl carbamate was dissolved $(2.849 \mathrm{~g}, 18.6 \mathrm{mmol})$ in $120 \mathrm{~mL}$ of acetonitrile. The solution was cooled down in a water-ice bath $\left(0-4{ }^{\circ} \mathrm{C}\right)$ and under efficient stirring a cold solution of potassium hydroxide $(0.758 \mathrm{~g} \mathrm{KOH}$ in $80 \mathrm{~mL}$ of water) was added. The solution was stirred 2 minutes, then a cold solution of tert-butyl hypochlorite $(1.344 \mathrm{~g}, 12.4 \mathrm{mmol})$ in $20 \mathrm{~mL}$ of acetonitrile was added; the solution was then stirred for $10 \mathrm{~min}$. A solution of potassium osmate $(88.9 \mathrm{mg}, 0.241$ mmol) in $20 \mathrm{~mL}$ of cold $\mathrm{H}_{2} \mathrm{O}$ was then added. After 2 min a solution of $\mathrm{DHQ}_{2} \mathrm{AQN}(280.0 \mathrm{mg}$, $0.326 \mathrm{mmol}$ ) in $20 \mathrm{~mL}$ of $\mathrm{CH}_{3} \mathrm{CN}$ was added, then a solution of $100 \mathrm{~mL}$ of cold acetonitrile was added and stirred for 3 min. Potassium phosphate buffer $(240 \mathrm{~mL}, \mathrm{pH}=7.57)$ was added, the cooling bath removed, and the solution allowed to stir for $5 \mathrm{~min}$ (the solution turned light green immediately). At this point the $\mathrm{pH}$ was checked and if necessary adjusted to $\mathrm{pH}=7.65 \pm 0.02$ by addition of a monobasic sodium phosphate solution. A solution of styrene (1.005 mg, $6.2 \mathrm{mmol})$ in $40 \mathrm{~mL}$ of acetonitrile was then added in one portion. The reaction mixture was vigorously stirred at room temperature $\left(21-23{ }^{\circ} \mathrm{C}\right)$. After $45-50 \mathrm{~min}$ the solution turns yellow, indicating completion (as verified by TLC disappearance of starting material).

The reaction mixture was cooled to $0-4{ }^{\circ} \mathrm{C}$ in an ice bath and $2.04 \mathrm{~g}$ of sodium sulfite in $20 \mathrm{~mL}$ of water was added. After $15 \mathrm{~min}$ of stirring the organic layer was separated and the aqueous layer was extracted with ethyl acetate $(3 \times 150 \mathrm{~mL})$. The combined organic extracts were washed with water $(2 \times 100 \mathrm{~mL})$ and brine $(3 \times 100 \mathrm{~mL})$, and dried over anhydrous magnesium sulfate. Solvent evaporation resulted $4.186 \mathrm{~g}$ of amorphous crystals, which was subjected to flash 
column chromatography (silica gel, 2:1=Hexane: EtOAc) to yield $1.410 \mathrm{~g}$ of 5 (71\% isolated yield, 73\%ee) as colorless crystals. The material was crystallized from EtOAc/hexane mixture (to a boiling suspension in hexanes $(130 \mathrm{~mL})$ EtOAc was added in portions until clear solution is obtained $(37 \mathrm{~mL}))$ to afford $0.380 \mathrm{~g}$ of colorless plate-like crystals $(20 \% \mathrm{ee})$ after filtration. The solution obtained after filtration was evaporated and recrystallized as described above second time to yield $0.882 \mathrm{~g}$ ( $43 \%$ of theoretical yield) of needle-like crystals ( $>99 \%$ ee), $0.106 \mathrm{~g}$ of material remained in solution $(>97 \%$ ee).

SFC (125psi $\mathrm{CO}_{2}, 12 \%, 3 \mathrm{~mL} / \mathrm{min} \mathrm{MeOH}$, Chiracel OD) $6.951 \mathrm{~min}(R), 7.384(S)$ $[\alpha]^{25}=29.64901\left(\mathrm{c}=.895, \mathrm{CHCl}_{3},[\alpha]^{25}{ }_{\mathrm{D}}=-16.7102\right.$ in $\mathrm{MeOH}$ at $\left.\mathrm{c}=.31\right)$ (enantiomer, obtained with DHQD $2 \mathrm{AQN}$ ligand, resulted $[\alpha]^{25} \mathrm{D}^{=-29.6437}\left(\mathrm{c}=.98, \mathrm{CHCl}_{3}\right)$ ).

The following compounds were synthesized according to the general protocol above on a 6.2 mmol scale; characterization data has been reported previously. ${ }^{1}$ Yields below are of the single regioisomer after chromatography, and the enatiomeric ratios were determined after crystallization, as described above.

Table S1. Products of aminohydroxylation. Characterization is as described in reference 1.

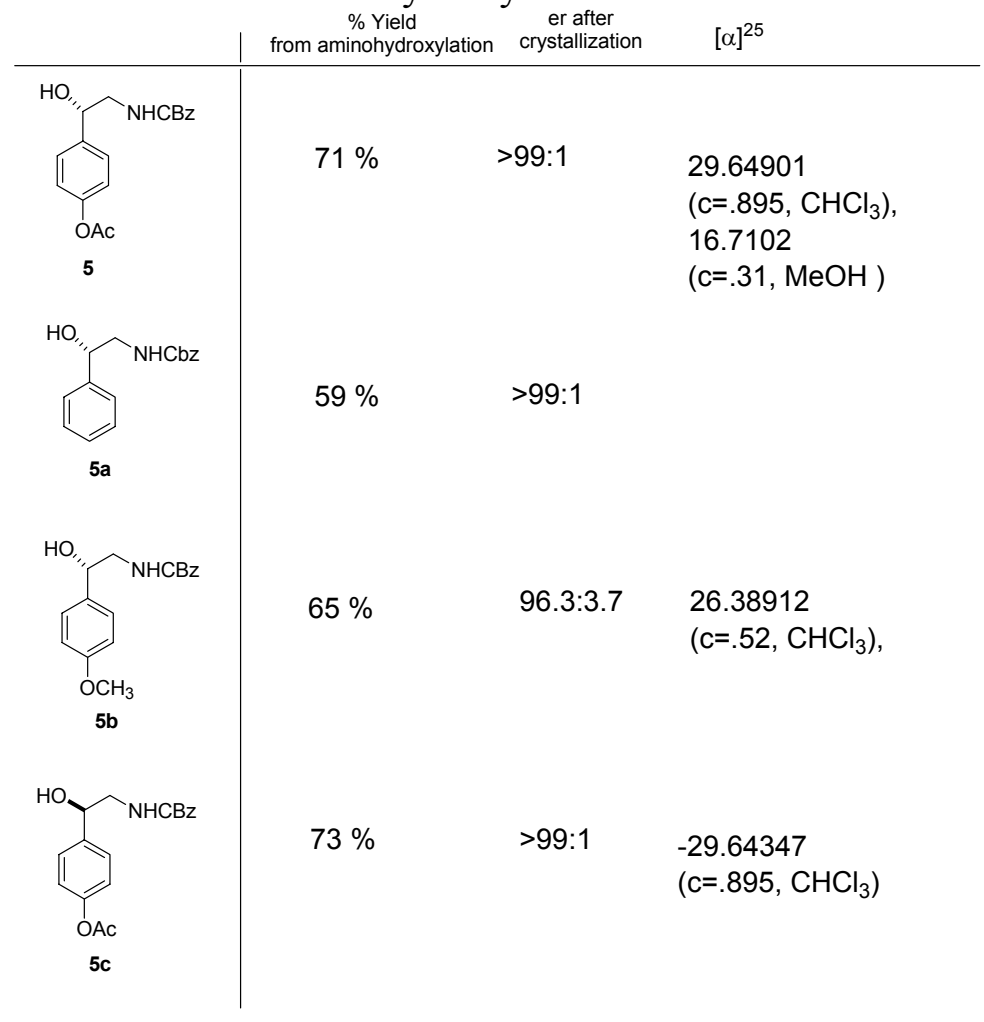

\section{General procedure for $O$-methylation of $N$-Cbz-2-amino-1-phenyl-ethanols}

As described for the synthesis of [(S)-2-methoxy-2-(4-acetoxy-phenyl)-ethyl]-carbamic acid benzyl ester (6):

An oven dried $50 \mathrm{~mL}$ round bottom flask, equipped with septum and Teflon coated magnetic stir bar, was charged with $5(329.5 \mathrm{mg}, 1 \mathrm{mmol})$, evacuated for $15 \mathrm{~min}$ at $0.01 \mathrm{~mm} \mathrm{Hg}$ and flushed with dry $\mathrm{N}_{2}$. After repeating the cycle three times, freshly distilled THF (15 mL) was added via syringe and the solution cooled in a dry ice-acetone bath $\left(-78{ }^{\circ} \mathrm{C}\right.$ external, $-74{ }^{\circ} \mathrm{C}$ internal) for 10 minutes. A solution of $n$-butylithium $(1.26 \mathrm{~mL}, 2.02 \mathrm{mmol}, 1.6 \mathrm{M}$ in hexanes) 
was added via syringe and after stirring for $1 \mathrm{~min}$ methyltriflate $(237 \mu \mathrm{L}, 344 \mathrm{mg}, 2.1 \mathrm{mmol})$ was added, and the mixture stirred for $1.5 \mathrm{~h}$ at $-74{ }^{\circ} \mathrm{C}$. The reaction mixture was poured onto $100 \mathrm{~mL}$ of cold $1 \% \mathrm{HCl}$ and extracted with ether $(4 \times 30 \mathrm{~mL})$, washed with $5 \%$ sodium bicarbonate and brine $(2 \times 30 \mathrm{~mL})$, and dried over anhydrous magnesium sulfate. Solvent evaporation resulted in $329.1 \mathrm{mg}$ of an oily substance, which was subjected to column chromatography (silica gel, 4:1=Hexane: EtOAc) to yield $246 \mathrm{mg}(71 \%)$ of colorless oil 6.

\title{
Yields for methylation reactions:
}
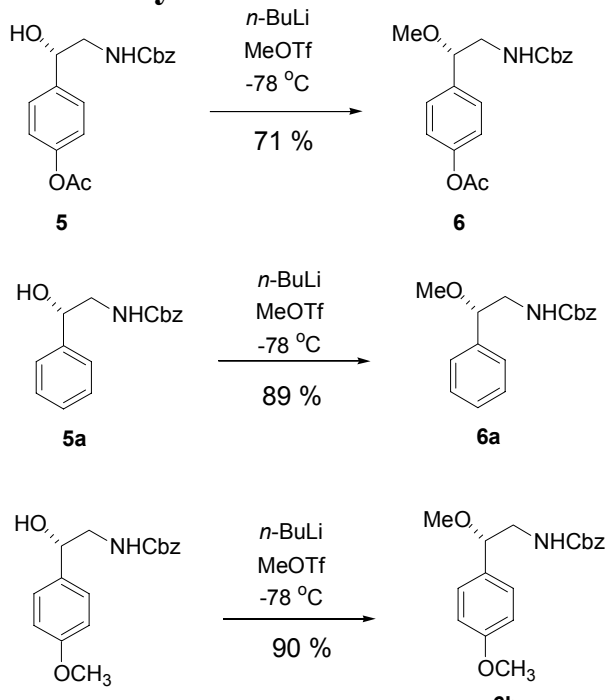

$5 b$

6b

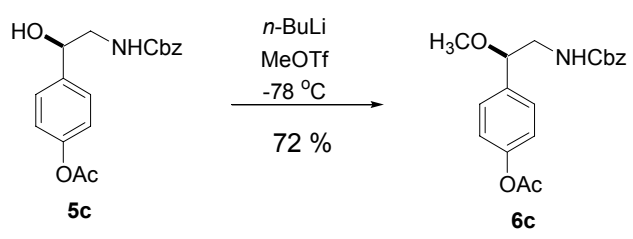

\section{Analytical data for alkylated carbamates.}

Acetic acid 4-(2-benzyloxycarbonylamino-1-(S)-methoxy-ethyl)-phenyl ester (6):<smiles>CO[C@H](CNC(=O)OCc1ccccc1)c1ccc(OC(C)=O)cc1</smiles>

\author{
$\mathrm{C}_{19} \mathrm{H}_{21} \mathrm{NO}_{5}$ \\ Exact Mass: 343.14 \\ Mol. Wt.: 343.37 \\ C, 66.46; H, 6.16; N, 4.08; O, 23.30
}

Synthesized by general procedure for methylation, above.

HMR ${ }^{1} \mathrm{H}\left(400 \mathrm{MHz}, \mathrm{CDCl}_{3}\right) \delta \mathrm{ppm}$ :

$7.35(\mathrm{~m}, 6 \mathrm{H}) ; 7.31(\mathrm{~d}, 2 \mathrm{H}, \mathrm{J} 1=8.6 \mathrm{~Hz}) ; 7.08(\mathrm{~d}, 2 \mathrm{H}, \mathrm{J} 1=8.5 \mathrm{~Hz}) ; 5.30$ (br. s, $1 \mathrm{H})$; $5.11(\mathrm{~d}, 2 \mathrm{H}, \mathrm{J} 1=2.7 \mathrm{~Hz}) ; 4.28(\mathrm{dd}, 1 \mathrm{H}, \mathrm{J} 1=8.6 \mathrm{~Hz}, \mathrm{~J} 2=3.7 \mathrm{~Hz}) ; 3.53(\mathrm{ddd}, 1 \mathrm{H}$, $\mathrm{J} 1=7.8 \mathrm{~Hz}, \mathrm{~J} 2=4.0 \mathrm{~Hz}, \mathrm{~J} 3=12.0 \mathrm{~Hz}$ ); 3.23 (s, 3H); 3.21 (ddd overlaid with singlet, $1 \mathrm{H}, \mathrm{J} 1=9.7 \mathrm{~Hz}, \mathrm{~J} 2=5.1 \mathrm{~Hz}, \mathrm{~J} 3=13.9 \mathrm{~Hz}) ; 2.29(\mathrm{~s}, 3 \mathrm{H})$.

NMR ${ }^{13} \mathbf{C}\left(\mathbf{1 2 5}\right.$ MHz, $\left.\mathbf{C D C l}_{3}\right) \delta$ ppm:

$169.3 ; 156.3 ; 150.4 ; 136.5 ; 136.4 ; 128.4 ; 128.0 ; 127.6 ; 121.6 ; 81.9 ; 66.6 ; 56.8$; $47.2 ; 21.0$. 
$\mathbf{R}_{f}=9 \mathrm{~mm} / 50 \mathrm{~mm}($ EtOAc $/$ Hexanes $=25 / 75) ;$ colorless oil

IR (thin film, $\mathrm{cm}^{-1}$ ): 3342, 3065, 3034, 2984, 2936, 2899, 2825, 1755, 1722, 1606, 1537, 1505 , $1455,1370,1216,1201,1165,1109,1075,1016,912,849,776$

MS (FAB): 344.09(M+1， 66.55); 312.09(M-31， 100.00); 268.09(44.44); 222.05(20.64); 179.06(22.31); $\quad 164.08(11.89) ; \quad 155.00(16.87) ; \quad 152.00(25.53) ; \quad 137.05(46.16) ;$ $118.98(55.43)$

HRMS (FAB): $344.1500\left(\mathrm{C}_{19} \mathrm{H}_{22} \mathrm{NO}_{5}\right.$, M+1; calc. 344.149798)

SFC (125psi $\mathrm{CO}_{2} ; 15 \%, 3 \mathrm{~mL} / \mathrm{min} \mathrm{MeOH}$, Chiracel OD): $3.672 \mathrm{~min}(\mathrm{R}), 3.865 \mathrm{~min}(\mathrm{~S})$, 1.11:98.89 er, $97.78 \%$ ee.

\title{
(2-Methoxy-2-phenyl-ethyl)-carbamic acid benzyl ester (6a):
}<smiles>CO[C@H](CNC(=O)OCc1ccccc1)c1ccccc1</smiles>
$\mathrm{C}_{17} \mathrm{H}_{19} \mathrm{NO}_{3}$ Exact Mass: 285.14
Mol. Wt.: 285.34
C, 71.56; H, 6.71; N, 4.91; O, 16.82

Synthesized by general procedure for methylation, above.

HMR ${ }^{1} \mathbf{H}\left(\mathbf{4 0 0} \mathbf{M H z}, \mathbf{C D C l}_{3}\right) \delta$ ppm: $7.37(\mathrm{~m}, 6 \mathrm{H}) ; 7.32(\mathrm{~m}, 4 \mathrm{H}) ; 5.28($ br. s, $1 \mathrm{H}) ; 5.12(\mathrm{~d}, 2 \mathrm{H}$, $\mathrm{J} 1=2.0 \mathrm{~Hz}) ; 4.29(\mathrm{dd}, 1 \mathrm{H}, \mathrm{J} 1=8.5 \mathrm{~Hz}, \mathrm{~J} 2=3.6 \mathrm{~Hz}) ; 3.57$ (ddd, $1 \mathrm{H}, \mathrm{J} 1=7.8 \mathrm{~Hz}, \mathrm{~J} 2=3.8 \mathrm{~Hz}$, $\mathrm{J} 3=12.0 \mathrm{~Hz}$ ); 3.28 (ddd overlaid with singlet, $1 \mathrm{H}, \mathrm{J} 1=8.7 \mathrm{~Hz}, \mathrm{~J} 2=4.1 \mathrm{~Hz}) ; 3.25(\mathrm{~s}, 3 \mathrm{H})$.

NMR ${ }^{13} \mathbf{C}\left(\mathbf{1 2 5} \mathbf{~ M H z}, \mathbf{C D C l}_{3}\right) \delta$ ppm: $168.5 ; 156.3 ; 138.9 ; 136.5 ; 128.5 ; 128.5 ; 128.1 ; 128.1 ;$ $126.6 ; 82.5 ; 66.6 ; 56.7 ; 47.2$.

$\mathbf{R}_{\boldsymbol{f}}=20 \mathrm{~mm} / 50 \mathrm{~mm}($ EtOAc/Hexanes $=25 / 75) ;$ colorless oil

IR (Thin film, $\mathrm{cm}^{-1}$ ) 3339, 3063, 3032, 2982, 2936, 2884, 2825, 1714, 1537, 1519, 1455, 1249, $1145,1109,1065,756$

MS (FAB): 286.09(M+1， 100.00); 254.07(M-31， 51.24); 210.1(23.17); 164.05(27.7); 134.97(29.82); 118.96(42.44);

HRMS (FAB): $286.1450\left(\mathrm{C}_{17} \mathrm{H}_{20} \mathrm{NO}_{3}, \mathrm{M}+1\right.$; calc 286.144319$)$

\section{[2-Methoxy-2-(4-methoxy-phenyl)-ethyl]-carbamic acid benzyl ester (6b):}<smiles>COc1ccc([C@@H](CNC(=O)OCc2ccccc2)OC)cc1</smiles>

\author{
$\mathrm{C}_{18} \mathrm{H}_{21} \mathrm{NO}_{4}$ \\ Exact Mass: 315.15 \\ Mol. Wt.: 315.36 \\ C, 68.55; H, 6.71; N, 4.44; O, 20.29
}

Synthesized by general procedure for methylation, above.

HMR ${ }^{1} \mathrm{H}\left(400 \mathrm{MHz}, \mathrm{CDCl}_{3}\right) \delta$ ppm:

$7.37(\mathrm{~m}, 5 \mathrm{H}) ; 7.22(\mathrm{~d}, 2 \mathrm{H}, \mathrm{J} 1=8.4 \mathrm{~Hz}) ; 6.89$ (d, 2H, J1=8.6 Hz); 5.21 (br. s, $1 \mathrm{H})$;

$5.11(\mathrm{~d}, 2 \mathrm{H}, \mathrm{J} 1=1.1 \mathrm{~Hz}) ; 4.22(\mathrm{dd}, 1 \mathrm{H}, \mathrm{J} 1=8.4 \mathrm{~Hz}, \mathrm{~J} 2=3.9 \mathrm{~Hz}) ; 3.81$ (s, 3H); 3.53 
(ddd, 1H, J1=7.8 Hz, J2=3.9 Hz, J3=12.2 Hz); 3.27 (ddd overlaid with singlet, $1 \mathrm{H}, \mathrm{J} 1=8.6 \mathrm{~Hz}, \mathrm{~J} 2=4.0 \mathrm{~Hz}, \mathrm{~J} 3=13.3 \mathrm{~Hz}$ ).

NMR ${ }^{13} \mathbf{C}\left(125 \mathrm{MHz}, \mathrm{CDCl}_{3}\right) \delta$ ppm:

$159.5 ; 156.3 ; 136.5 ; 130.9 ; 128.5 ; 128.1 ; 127.9 ; 114.0 ; 82.0 ; 66.7 ; 56.5 ; 55.2$; 47.2 .

$\mathbf{R}_{\boldsymbol{f}}=14 \mathrm{~mm} / 50 \mathrm{~mm}($ EtOAc/Hexanes $=25 / 75)$; colorless oil

$[\boldsymbol{\alpha}]^{\mathbf{2 5}}{ }_{\mathbf{D}}=26.638912\left(\mathrm{c}=.895, \mathrm{CHCl}_{3}\right)$

IR (thin film, $\mathrm{cm}^{-1}$ ): 3377, 3002, 2937, 2840, 1708, 1611, 1523, 1513, 1463, 1444, 1365, 1308, $1262,1235,1173,1113,1078,1027,986,826,760$

MS (FAB): 316.09(M+1， 8.04); 284.07(M-31， 100.00); 240.1(14.64); 194.06(17.08); $151.06(39.63) ; 134.99(23.88) ; 118.97(34.28)$

HRMS (FAB): $316.1553\left(\mathrm{C}_{18} \mathrm{H}_{22} \mathrm{NO}_{4}, \mathrm{M}+1\right.$, calc. 316.154883$)$

Acetic acid 4-(2-benzyloxycarbonylamino-1-(S)-methoxy-ethyl)-phenyl ester (6c):<smiles>CO[C@H](CNC(=O)OCc1ccccc1)c1ccc(OC(C)=O)cc1</smiles>

\author{
$\mathrm{C}_{19} \mathrm{H}_{21} \mathrm{NO}_{5}$ \\ Exact Mass: 343.14 \\ Mol. Wt.: 343.37 \\ C, 66.46; H, 6.16; N, 4.08; O, 23.30
}

Synthesized by general procedure for methylation, above.

HMR ${ }^{1} \mathrm{H}\left(400 \mathrm{MHz}, \mathrm{CDCl}_{3}\right) \delta \mathrm{ppm}$ :

$7.36(\mathrm{~m}, 5 \mathrm{H}) ; 7.31(\mathrm{~d}, 2 \mathrm{H}, \mathrm{J} 1=6.6 \mathrm{~Hz}) ; 7.08(\mathrm{~d}, 2 \mathrm{H}, \mathrm{J} 1=8.6 \mathrm{~Hz}) ; 5.22$ (br. s, $1 \mathrm{H})$;

$5.11(\mathrm{~d}, 2 \mathrm{H}, \mathrm{J} 1=1.3 \mathrm{~Hz}) ; 4.28(\mathrm{dd}, 1 \mathrm{H}, \mathrm{J} 1=8.5 \mathrm{~Hz}, \mathrm{~J} 2=4.0 \mathrm{~Hz}) ; 3.54(\mathrm{ddd}, 1 \mathrm{H}$, $\mathrm{J} 1=7.8 \mathrm{~Hz}, \mathrm{~J} 2=4.0 \mathrm{~Hz}, \mathrm{~J} 3=12.0 \mathrm{~Hz}$ ); $3.24(\mathrm{~s}, 3 \mathrm{H}) ; 3.21$ (ddd overlaid with singlet, $1 \mathrm{H}, \mathrm{J} 1=9.7 \mathrm{~Hz}, \mathrm{~J} 2=5.4 \mathrm{~Hz}, \mathrm{~J} 3=13.9 \mathrm{~Hz}) ; 2.30(\mathrm{~s}, 3 \mathrm{H})$.

NMR ${ }^{13} \mathbf{C}\left(100 \mathrm{MHz}^{10} \mathrm{CDCl}_{3}\right) \delta$ ppm:

$169.4 ; 156.3 ; 150.4 ; 136.5 ; 136.4 ; 128.5 ; 128.1 ; 127.7 ; 121.7 ; 82.0 ; 66.7 ; 56.9$; $47.3 ; 21.1$.

$\mathbf{R}_{\boldsymbol{f}}=9 \mathrm{~mm} / 50 \mathrm{~mm}($ EtOAc/Hexanes $=25 / 75)$; colorless oil

$[\boldsymbol{\alpha}]^{25}=-29.6437\left(\mathrm{c}=.98, \mathrm{CHCl}_{3}\right)$

IR (thin film, $\mathrm{cm}^{-1}$ ): 3342, 3065, 3034, 2984, 2937, 2899, 2825, 1755, 1722, 1606, 1531, 1505, $1455,1370,1217,1203,1165,1110,1074,1016,912,849,776$

MS (FAB): 344.09(M+1， 56.86); 312.05(M-31， 100.00); 268.09(60.67); 222.05(20.90); 179.05(33.58); 167.02(18.52); 165.00(18.90); 155.00(36.59); 151.97(42.26); 137.05(62.70); 118.98(72.01)

HRMS (FAB): $344.1500\left(\mathrm{C}_{19} \mathrm{H}_{22} \mathrm{NO}_{5}, \mathrm{M}+1\right.$; calc. 344.149798$)$

SFC (125psi $\mathrm{CO}_{2} ; 8 \%, 3 \mathrm{~mL} / \mathrm{min} \mathrm{MeOH}$, Chiracel OD): $7.83 \mathrm{~min}(\mathrm{R}),>99 \%$ ee.

\title{
Procedure and Analytical data for hydrolysis of 6 and $6 c$ :
}

[2-(4-Hydroxy-phenyl)-2-(S)-methoxy-ethyl]-carbamic acid benzyl ester (6d):

To a solution of $6(160 \mathrm{mg}, 0.46 \mathrm{mmol})$ in EtOH $(5 \mathrm{~mL}) 0.568 \mathrm{~g}$ of a freshly prepared solution of potassium hydroxide $\left(253.2 \mathrm{mg}\right.$ in $\left.5.013 \mathrm{~g} \mathrm{H}_{2} \mathrm{O}, 0.045 \mathrm{M}\right)$ was added. The mixture 
was stirred at $23-25{ }^{\circ} \mathrm{C}$ for $1 \mathrm{~h}$ (completion monitored by TLC) and neutralized with $0.1 \% \mathrm{HCl}$ (neutral by $\mathrm{pH}$ indicator paper). Solvent was evaporated in vacuo and the residue dissolved in ethyl acetate and flash filtered through a pad of silica gel to remove inorganic impurities. The silica gel was washed with ethyl acetate, fractions combined and solvent evaporated in vacuo to afford $136 \mathrm{mg}(97 \%)$ of $\mathbf{6 d}$.

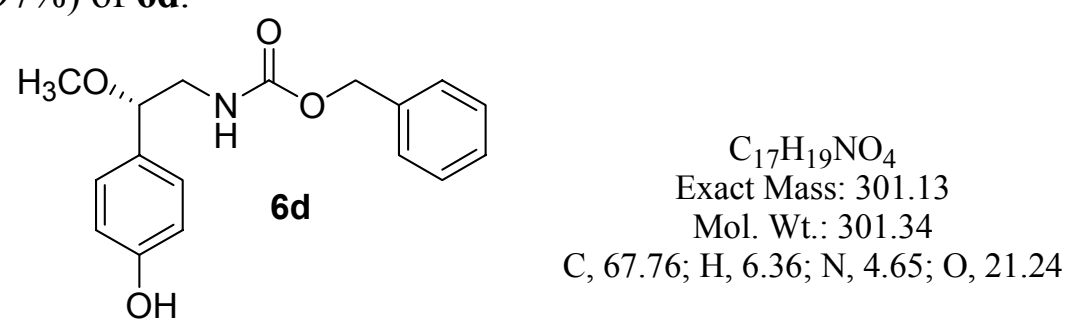

HMR ${ }^{1} \mathrm{H}\left(500 \mathrm{MHz}, \mathrm{CDCl}_{3}\right) \delta \mathrm{ppm}$ :

7.46 (br. s, $1 \mathrm{H}) ; 7.35$ (m, 5H); 7.11 (d, 2H, J1=8.3 Hz); 6.83 (d, 2H, J1=8.3 Hz);

5.47 (br. s, $1 \mathrm{H}) ; 5.13$ (s, 2H); 4.21 (dd, 1H, J1=8.6 Hz, J2=3.7 Hz); 3.53 (ddd, 1H,

$\mathrm{J} 1=7.7 \mathrm{~Hz}, \mathrm{~J} 2=3.9 \mathrm{~Hz}, \mathrm{~J} 3=12.1 \mathrm{~Hz}$ ); 3.27 (ddd overlaid with singlet, $1 \mathrm{H}, \mathrm{J} 1=8.7$

NMR ${ }^{13} \mathbf{C}\left(\mathbf{1 2 5} \mathbf{M H z}, \mathbf{C D C l}_{3}\right) \delta$ ppm:

$\mathrm{Hz}, \mathrm{J} 2=4.1 \mathrm{~Hz}, \mathrm{~J} 3=13.3 \mathrm{~Hz}) ; 3.20(\mathrm{~s}, 3 \mathrm{H})$.

$156.8 ; 156.4 ; 136.2 ; 129.8 ; 128.4 ; 128.1 ; 128.0 ; 127.9 ; 115.5 ; 82.0 ; 66.9 ; 56.4$; 47.2 .

$\mathbf{R}_{\boldsymbol{f}}=14 \mathrm{~mm} / 50 \mathrm{~mm}($ EtOAc/Hexanes $=25 / 75)$;

\section{[2-(4-Hydroxy-phenyl)-2-(R)-methoxy-ethyl]-carbamic acid benzyl ester (6e):}

To a solution of $\mathbf{6 c}(132 \mathrm{mg}, 0.35 \mathrm{mmol})$ in EtOH $(5 \mathrm{~mL}) 0.469 \mathrm{~g}$ of a freshly prepared solution of potassium hydroxide $\left(253.2 \mathrm{mg}\right.$ in $5.013 \mathrm{~g} \mathrm{H}_{2} \mathrm{O}, 0.045 \mathrm{M}, 1.1$ eq. $)$ was added. The mixture was stirred at $23-25{ }^{\circ} \mathrm{C}$ for $1 \mathrm{~h}$ (completion monitored by TLC) and neutralized with $0.1 \% \mathrm{HCl}$ (neutral by $\mathrm{pH}$ indicator paper). Solvent was evaporated in vacuo and the residue dissolved in ethyl acetate and flash filtered through a pad of silica gel to remove inorganic impurities. The silica gel was washed with ethyl acetate, fractions combined and solvent evaporated in vacuo to afford $107 \mathrm{mg}(92 \%)$ of $6 \mathbf{e}$.
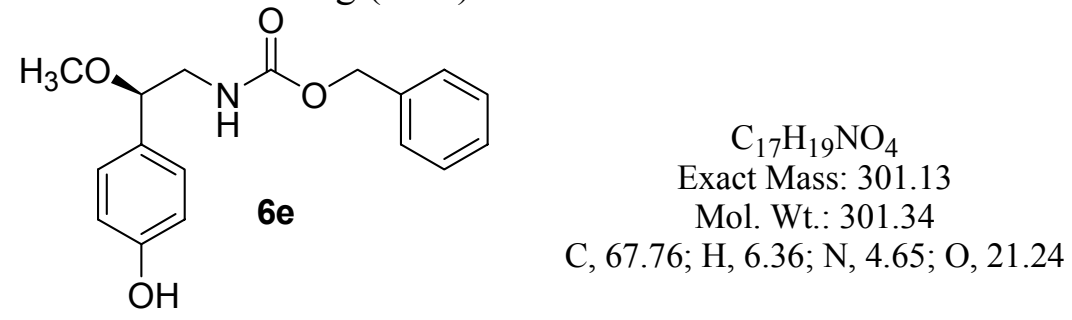

HMR ${ }^{1} \mathrm{H}\left(400 \mathrm{MHz}, \mathrm{CDCl}_{3}\right) \delta \mathrm{ppm}$ :

7.35 (m, 5H); 7.17 (br. s, $1 \mathrm{H}) ; 7.10$ (d, 2H, J1=8.3 Hz); 6.82 (d, 2H, J1=8.3 Hz);

5.42 (br. s, $1 \mathrm{H}) ; 5.13$ (s, 2H); $4.20(\mathrm{dd}, 1 \mathrm{H}, \mathrm{J} 1=8.6 \mathrm{~Hz}, \mathrm{~J} 2=3.7 \mathrm{~Hz}) ; 3.52$ (ddd, $1 \mathrm{H}$,

$\mathrm{J} 1=7.7 \mathrm{~Hz}, \mathrm{~J} 2=3.7 \mathrm{~Hz}, \mathrm{~J} 3=12.1 \mathrm{~Hz}$ ); 3.26 (ddd overlaid with singlet, $1 \mathrm{H}, \mathrm{J} 1=8.7$

$\mathrm{Hz}, \mathrm{J} 2=4.1 \mathrm{~Hz}, \mathrm{~J} 3=13.3 \mathrm{~Hz}) ; 3.20(\mathrm{~s}, 3 \mathrm{H})$.

NMR ${ }^{13} \mathbf{C}\left(\mathbf{1 0 0} \mathbf{M H z}, \mathbf{C D C l}_{3}\right) \delta$ ppm: 156.8; 156.3; 136.2; 130.0; 128.5; 128.2; 128.1; 128.0; $115.5 ; 82.1 ; 66.9 ; 56.4 ; 47.3$.

$\mathbf{R}_{\boldsymbol{f}}=14 \mathrm{~mm} / 50 \mathrm{~mm}($ EtOAc $/$ Hexanes $=25 / 75)$;

Compounds $\mathbf{6 f}$ and $\mathbf{6 g}$ (see Table S2, below) were obtained by the hydrolysis of $\mathbf{5}$ and $\mathbf{5 c}$, respectively. This hydrolysis was performed exactly as described for $\mathbf{6 d}$, above. 


\section{General procedure for deprotection of $\mathrm{Cbz}$ group}

As described the synthesis of (S)-4-(2-Amino-1-methoxy-ethyl)-phenol (9):

$5 \% \mathrm{Pd} / \mathrm{C}$ (48 mg, $2.4 \mathrm{mg} \mathrm{Pd}, 1.5 \mathrm{wt} \%$ ) was loaded in a $25 \mathrm{~mL}$ tube-shaped flask, equipped with a magnetic stirrer, a hydrogen balloon and a vacuum outlet. The flask was evacuated for $5 \mathrm{~min}$ at $0.001 \mathrm{~mm} \mathrm{Hg}$ and flushed with $\mathrm{H}_{2}$. After repeating the cycle 4 times the catalyst was suspended in EtOH $(4 \mathrm{~mL})$ and $\mathbf{6 d}(136.0 \mathrm{mg}, 0.45 \mathrm{mmol})$, was added as a solution in EtOH $(2 \mathrm{~mL})$ and the mixture was stirred under hydrogen atmosphere for $8 \mathrm{~h}$. Upon completion (monitored by TLC by disappearance of the starting material), the solution was filtered with celite. The celite was washed with $\mathrm{EtOH}(3 \times 3 \mathrm{~mL})$ and solvent was removed in vacuum and the residue dried at $20-23{ }^{\circ} \mathrm{C}$ for $1 \mathrm{~h}$ at $0.01 \mathrm{~mm} \mathrm{Hg}$ to give $73.6 \mathrm{mg}$ of a crystalline substance (Table S2). The presence of the amine was verified by ninhydrin stain and the product was used in the next step for coupling. Due to relative instability of the amine products, they were immediately coupled to the appropriate acid, and were not characterized. For the library synthesis, all Cbz deprotections were performed in parallel, and the amines were then used immediately to create the library. 
Table S2. Synthesis of amine building blocks by deprotection of carbamates.

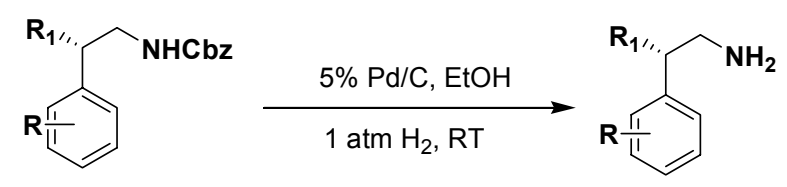

Entry




\title{
Procedure and Analytical data for amides $\left({ }^{1} \mathrm{H}\right.$ and ${ }^{13} \mathrm{C}$ spectra follow $)$
}

Amides were prepared by both solution and solid phase couplings of appropriate amine and acid building blocks. Solution phase reaction was generally used for scale up reactions, but required more tedious chromatography to purify the products. The ${ }^{1} \mathrm{H}$ and ${ }^{13} \mathrm{C}$ spectra are below.

3-(4-Hydroxy-3-(S)-methoxy-phenyl)-N-[2-(4-hydroxy-phenyl)-2-methoxy-ethyl]acrylamide (1, 9-D): METHOD 1-solid-phase coupling. An oven dried $15 \mathrm{~mL}$ round bottom flask, equipped with a Teflon-coated magnetic stir bar, was charged with PS-CDI (45 $\mathrm{mg}, 0.0576 \mathrm{mmol}$, 2eq. $1.28 \mathrm{mmol} / \mathrm{g}$ ), evacuated for $15 \mathrm{~min}$ at $0.01 \mathrm{~mm} \mathrm{Hg}$ and flushed with dry $\mathrm{N}_{2}$. After repeating the cycle three times, freshly distilled THF $(5 \mathrm{~mL})$ was added via syringe followed by a solution of ferulic acid $(6.0 \mathrm{mg}, 0.031 \mathrm{mmol}, 1.1 \mathrm{eq})$ in THF $(0.4 \mathrm{~mL})$. Compound 9 (4.7 mg, $0.028 \mathrm{mmol}, 1$ eq.) was added as solution in THF $(0.5 \mathrm{~mL})$ and the mixture is stirred at $20-22{ }^{\circ} \mathrm{C}$ for $6-8 \mathrm{~h}$. The beads were filtered off and washed with THF $(3 \times 1 \mathrm{~mL})$. The organic washes were combined and solvent evaporated to afford $9.1 \mathrm{mg}$ of oily substance, which was subjected to column chromatography (silica gel, 1:7=Hexane:EtOAc) to yield $3.3 \mathrm{mg}(37 \%)$ of 9-D as an amorphous substance.

\section{3-(4-Hydroxy-3-(S)-methoxy-phenyl)-N-[2-(4-hydroxy-phenyl)-2-methoxy-ethyl]-} acrylamide (1, 9-D): METHOD 2-solution-phase coupling. An oven dried $25 \mathrm{~mL}$ round bottom flask, equipped with a Teflon coated magnetic stir bar, was evacuated for 15 min at 0.01 $\mathrm{mm} \mathrm{Hg}$ and flushed with dry $\mathrm{N}_{2}$. After repeating the cycle three times, the flask was charged with dicyclohexylcarbodiimide $(19.5 \mathrm{mg}, 0.095 \mathrm{mmol}$, as a solution in THF, $2.1 \mathrm{~mL})$ followed by a solution of $\mathbf{D}(18.3 \mathrm{mg}, 0.095 \mathrm{mmol}$ per $2.1 \mathrm{~mL})$ in THF $(2.1 \mathrm{~mL})$. Amine $9(15.1 \mathrm{mg}, 0.09$ mmol) was added as a solution in THF/DMF $(8: 1,2.1 \mathrm{~mL})$ and the mixture was stirred at 20-22 ${ }^{\circ} \mathrm{C}$ for $10 \mathrm{~h}$. Upon completion (monitored by TLC, by disappearance of the amine) solvent evaporation resulted $52.1 \mathrm{mg}$ of a viscous oil. The mixture then was subjected to column chromatography (silica gel, 1:4=Hexane: EtOAc) to yield $21.4 \mathrm{mg}(71 \%)$ of 9-D as a lightyellow viscous oil.<smiles>COc1cc(/C=C/C(=O)NC[C@H](OC)c2ccc(O)cc2)ccc1O</smiles>

\author{
$\mathrm{C}_{19} \mathrm{H}_{21} \mathrm{NO}_{5}$ \\ Exact Mass: 343.14 \\ Mol. Wt.: 343.37 \\ C, 66.46; H, 6.16; N, 4.08; O, 23.30
}

NMR ${ }^{13} \mathrm{C}\left(125 \mathrm{MHz}, \mathrm{CD}_{3} \mathrm{OD}\right) \delta \mathrm{ppm}$ :

7.43 (d, 1H, J1=15.9 Hz); 7.17 (app. dt, 2H, J1=6.4 Hz, J2=1.7 Hz); 7.12 (d, 1H, $\mathrm{J} 1=1.6 \mathrm{~Hz}) ; 7.03$ (dd, 1H, J1=8.1 Hz, J2=1.7 Hz); 6.79 (d, 1H, J1=1.7 Hz); 6.79 $(\mathrm{d}, 1 \mathrm{H}, \mathrm{J} 1=2.4 \mathrm{~Hz}) ; 6.78(\mathrm{~d}, 1 \mathrm{H}, \mathrm{J} 1=1.9 \mathrm{~Hz}) ; 6.47$ (d, 1H, J1=15.9 Hz); 4.24 (dd, $1 \mathrm{H}, \mathrm{J} 1=8.6 \mathrm{~Hz}, \mathrm{~J} 2=4.5 \mathrm{~Hz}) ; 3.87(\mathrm{~s}, 3 \mathrm{H}) ; 3.52(\mathrm{dd}, 1 \mathrm{H}, \mathrm{J} 1=13.7 \mathrm{~Hz}, \mathrm{~J} 2=4.5 \mathrm{~Hz})$; $3.40(\mathrm{dd}, 1 \mathrm{H}, \mathrm{J} 1=13.7 \mathrm{~Hz}, \mathrm{~J} 2=8.6 \mathrm{~Hz}) ; 3.20(\mathrm{~s}, 3 \mathrm{H})$.

NMR ${ }^{13} \mathrm{C}\left(125 \mathrm{MHz}, \mathrm{CD}_{3} \mathrm{OD}\right) \delta \mathrm{ppm}$ :

$169.2 ; 158.6 ; 149.9 ; 149.3 ; 142.3 ; 131.4 ; 129.2 ; 128.3 ; 127.1 ; 123.3 ; 118.7$; $116.5 ; 116.3 ; 111.5 ; 83.3 ; 56.8 ; 56.4 ; 47.1$. 
$\mathbf{R}_{f}=14 \mathrm{~mm} / 50 \mathrm{~mm}($ EtOAc $/$ Hexanes $=75 / 25)$;

$[\mathbf{\alpha}]^{\mathbf{2 5}} \mathbf{D}=-28.8805(\mathrm{c}=1.23, \mathrm{MeOH})$

IR $\left(\mathrm{KBr}, \mathrm{cm}^{-1}\right): 3398,2937,2826,1654,1648,1596,1515,1458,1271,1254,1209,1032,837$

MS (FAB): 344.2(M+1), 312.1(M-31)

HRMS (FAB): $344.1500\left(\mathrm{C}_{19} \mathrm{H}_{22} \mathrm{NO}_{5}, \mathrm{M}+1\right.$; calc. 344.149798$)$

MS (ESI) (m/z): 708.85(2M+Na, 6.60), 343.84(M+1, 100.00), 312.05(M-31, 43.11)

UV (PDA; $\left.\lambda_{\max }, \mathrm{nm}\right): 225,295,320$;

3-(4-Hydroxy-3-methoxy-phenyl)- $N$-(2-hydroxy-2-phenyl-ethyl)-acrylamide (12-D): An oven dried $50 \mathrm{~mL}$ round bottom flask, equipped with a Teflon coated magnetic stir bar, was evacuated for $15 \mathrm{~min}$ at $0.01 \mathrm{~mm} \mathrm{Hg}$ and flushed with dry $\mathrm{N}_{2}$. After repeating the cycle three times, the flask was charged with dicyclohexylcarbodiimide $(59.3 \mathrm{mg}, 0.287 \mathrm{mmol}$, as a solution in THF, $5 \mathrm{~mL})$ followed by a solution of $\mathbf{D}(53.4 \mathrm{mg}, 0.275 \mathrm{mmol})$ in THF $(5 \mathrm{~mL})$. Amine 12 (34.3 $\mathrm{mg}, 0.25 \mathrm{mmol})$ was added as solution in THF/DMF $(8: 1,5 \mathrm{~mL})$ and the mixture was stirred at $20-22{ }^{\circ} \mathrm{C}$ for $10 \mathrm{~h}$. Upon completion (monitored by TLC by disappearance of the amine) solvent evaporation resulted $146.1 \mathrm{mg}$ of viscous oily substance. The mixture then was subjected to column chromatography (silica gel, 1:4=Hexane: EtOAc) to yield $32.1 \mathrm{mg}(42 \%)$ of 12-D as a viscous oil.

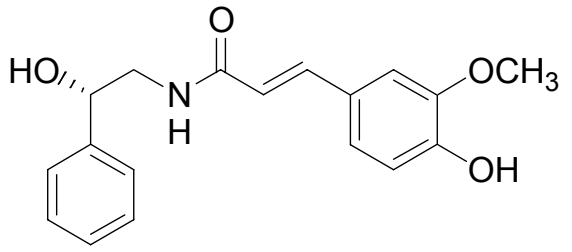

$\mathrm{C}_{18} \mathrm{H}_{19} \mathrm{NO}_{4}$
Exact Mass: 313.13
Mol. Wt.: 313.35
$\mathrm{C}, 68.99 ; \mathrm{H}, 6.11 ; \mathrm{N}, 4.47 ; \mathrm{O}, 20.42$

HMR ${ }^{1} \mathbf{H}\left(\mathbf{C D}_{3} \mathrm{OD}\right) \delta$ ppm:

$7.43(\mathrm{~d}, 1 \mathrm{H}, \mathrm{J} 1=15.6 \mathrm{~Hz}) ; 7.40$ (d, 1H, J1=1.5 Hz); 7.38 (s, 1H); 7.31 (app. t, $2 \mathrm{H}, \mathrm{J} 1=7.8 \mathrm{~Hz}$ ); 7.24 (app. tt, $1 \mathrm{H}, \mathrm{J} 1=7.2 \mathrm{~Hz}, \mathrm{~J} 2=2.2 \mathrm{~Hz}) ; 7.10$ (d, $1 \mathrm{H}$, $\mathrm{J} 1=2.0 \mathrm{~Hz}) ; 7.02(\mathrm{dd}, 1 \mathrm{H}, \mathrm{J} 1=8.0 \mathrm{~Hz}, \mathrm{~J} 2=1.7 \mathrm{~Hz}) ; 6.78(\mathrm{~d}, 1 \mathrm{H}, \mathrm{J} 1=8.2 \mathrm{~Hz})$; $6.45(\mathrm{~d}, 1 \mathrm{H}, \mathrm{J} 1=15.7 \mathrm{~Hz})$.

NMR ${ }^{13} \mathrm{C}\left(125 \mathrm{MHz}, \mathrm{CD}_{3} \mathrm{OD}\right) \delta \mathrm{ppm}$ :

$169.5 ; 149.9 ; 149.3 ; 144.0 ; 142.3 ; 129.4 ; 128.6 ; 128.2 ; 127.2 ; 123.3$;

$118.5 ; 116.4 ; 111.5 ; 73.7 ; 56.3 ; 48.4$.

$\mathbf{R}_{\boldsymbol{f}}=15.5 \mathrm{~mm} / 50 \mathrm{~mm}($ EtOAc $/$ Hexanes $=75 / 25)$;

MS (FAB): $314.1(\mathrm{M}+1)$

HRMS (FAB): $314.1393\left(\mathrm{C}_{18} \mathrm{H}_{20} \mathrm{NO}_{4}, \mathrm{M}+1\right.$; calc. 314.139233$)$

MS (ESI) (m/z): 313.93(M+1, 100.00), 296.15(M-17, 7.54)

UV (PDA; $\left.\lambda_{\max }, \mathrm{nm}\right): 220,295,320$;

$N$-[2-(S)-Hydroxy-2-(4-hydroxy-phenyl)-ethyl]-3-(4-hydroxy-3-methoxy-phenyl)acrylamide (13-D): An oven dried $50 \mathrm{~mL}$ round bottom flask, equipped with a Teflon coated magnetic stir bar, was evacuated for $15 \mathrm{~min}$ at $0.01 \mathrm{~mm} \mathrm{Hg}$ and flushed with dry $\mathrm{N}_{2}$. After repeating the cycle three times, the flask was charged with dicyclohexylcarbodiimide $(59.3 \mathrm{mg}$, $0.287 \mathrm{mmol}$, as a solution in THF, $5 \mathrm{~mL})$ followed by a solution of $\mathbf{D}(53.4 \mathrm{mg}, 0.275 \mathrm{mmol})$ in THF (5 mL). Amine $13(38.3 \mathrm{mg}, 0.25 \mathrm{mmol})$ was added as solution in THF/DMF (8:1, $5 \mathrm{~mL})$ and the mixture was stirred at $20-22{ }^{\circ} \mathrm{C}$ for $10 \mathrm{~h}$. Upon completion (monitored by TLC by 
disappearance of the amine) solvent evaporation resulted $147 \mathrm{mg}$ of a viscous oily substance. The crude reaction mixture then was subjected to column chromatography (silica gel, 1:4=Hexane: EtOAc) to yield $45 \mathrm{mg}(56 \%)$ of 13-D as a viscous oil.

HMR ${ }^{1} \mathbf{H}\left(\mathrm{CD}_{3} \mathrm{OD}\right) \delta \mathrm{ppm}$ :

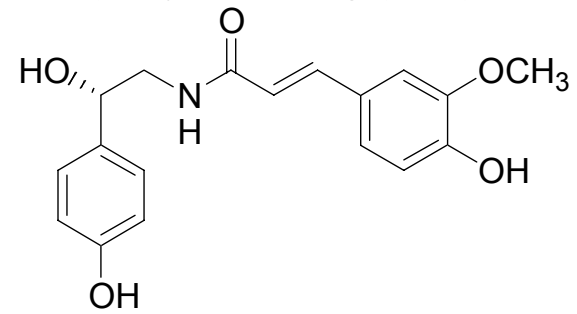

\author{
$\mathrm{C}_{18} \mathrm{H}_{19} \mathrm{NO}_{5}$ \\ Exact Mass: 329.13 \\ Mol. Wt.: 329.35 \\ $\mathrm{C}, 65.64 ; \mathrm{H}, 5.81 ; \mathrm{N}, 4.25 ; \mathrm{O}, 24.29$
}

7.42 (d, 1H, J1=15.6 Hz); 7.20 (app. dt, 2H, J1=8.4 Hz); 7.09 (d, 1H, J1=1.7 Hz);

$7.01(\mathrm{dd}, 1 \mathrm{H}, \mathrm{J} 1=8.3 \mathrm{~Hz}, \mathrm{~J} 2=2.0 \mathrm{~Hz}) ; 6.75$ (app. t, 3H, J1=8.5 Hz); 6.45 (d, 1H,

$\mathrm{J} 1=15.8 \mathrm{~Hz}) ; 4.71(\mathrm{dd}, 1 \mathrm{H}, \mathrm{J} 1=7.7 \mathrm{~Hz}, \mathrm{~J} 2=4.8 \mathrm{~Hz}) ; 3.85(\mathrm{~s}, 3 \mathrm{H}) ; 3.53(\mathrm{dd}, 1 \mathrm{H}$,

$\mathrm{J} 1=13.3 \mathrm{~Hz}, \mathrm{~J} 2=4.8 \mathrm{~Hz}) ; 3.43(\mathrm{dd}, 1 \mathrm{H}, \mathrm{J} 1=13.5 \mathrm{~Hz}, \mathrm{~J} 2=7.8 \mathrm{~Hz})$.

NMR ${ }^{13} \mathbf{C}\left(125 \mathrm{MHz}, \mathrm{CD}_{\mathbf{3}} \mathrm{OD}\right) \delta \mathrm{ppm}$ :

$169.4 ; 158.1 ; 149.8 ; 149.2 ; 142.2 ; 134.7 ; 128.5 ; 128.2 ; 123.3 ; 118.6 ; 116.4$;

$116.1 ; 111.5 ; 73.4 ; 56.3 ; 48.4$.

$\mathbf{R}_{\boldsymbol{f}}=6 \mathrm{~mm} / 50 \mathrm{~mm}($ EtOAc/Hexanes $=75 / 25)$; amorphous crystals

$[\boldsymbol{\alpha}]^{\mathbf{2 5}} \mathbf{D}^{=-37.5557}(\mathrm{c}=1.376, \mathrm{MeOH})$

IR $\left(\mathrm{KBr}, \mathrm{cm}^{-1}\right): 3338,3276,2938,2875,1654,1599,1559,1517,1449,1430,1369,1253$,

1167, 1127, 1075, 1030, 966, 835;

MS (FAB): $330.1(\mathrm{M}+1)$

HRMS (FAB): $330.1335\left(\mathrm{C}_{18} \mathrm{H}_{20} \mathrm{NO}_{5}, \mathrm{M}+1\right.$; calc. 330.134148$)$

MS (ESI) (m/z): 712.04(10.07), 329.8(M+1, 100.00), 312.04(M-17, 87.74)

UV (PDA; $\left.\lambda_{\max }, \mathrm{nm}\right): 230,295,320$;

$N$-[2-(R)-Hydroxy-2-(4-hydroxy-phenyl)-ethyl]-3-(4-hydroxy-3-methoxy-phenyl)-

acrylamide (15-D): An oven dried $50 \mathrm{~mL}$ round bottom flask, equipped with a Teflon coated magnetic stir bar, was evacuated for $15 \mathrm{~min}$ at $0.01 \mathrm{~mm} \mathrm{Hg}$ and flushed with dry $\mathrm{N}_{2}$. After repeating the cycle three times, the flask was charged with dicyclohexylcarbodiimide $(59.3 \mathrm{mg}$, $0.287 \mathrm{mmol}$, as solution in THF, $5 \mathrm{~mL})$ followed by a solution of $\mathbf{D}(53.4 \mathrm{mg}, 0.275 \mathrm{mmol})$ in THF (5 mL). Amine 15 (38.3 mg, $0.25 \mathrm{mmol})$ was added as solution in THF/DMF (8:1, $5 \mathrm{~mL})$ and the mixture was stirred at $20-22{ }^{\circ} \mathrm{C}$ for $10 \mathrm{~h}$. Upon completion (monitored by TLC by disappearance of the amine) solvent evaporation resulted $149.1 \mathrm{mg}$ of a viscous oily substance. The crude reaction mixture then was subjected to column chromatography (silica gel, 1:4=Hexane: EtOAc) to yield $32.0 \mathrm{mg}(40 \%)$ of 15-D as a viscous oil.

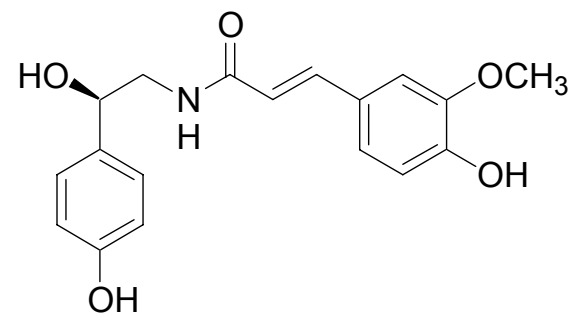

\author{
$\mathrm{C}_{18} \mathrm{H}_{19} \mathrm{NO}_{5}$ \\ Exact Mass: 329.13 \\ Mol. Wt.: 329.35 \\ C, 65.64; H, 5.81; N, 4.25; O, 24.29
}

$\mathrm{HMR}^{1} \mathbf{H}\left(\mathbf{C D}_{\mathbf{3}} \mathrm{OD}\right) \delta \mathrm{ppm}$ :

7.43 (d, 1H, J1=15.9 Hz); 7.20 (app. dt, 2H, J1=8.9 Hz); 7.09 (d, 1H, J1=1.9 Hz); $7.01(\mathrm{dd}, 1 \mathrm{H}, \mathrm{J} 1=8.2 \mathrm{~Hz}, \mathrm{~J} 2=1.5 \mathrm{~Hz}) ; 6.75$ (app. t, 3H, J1=7.6 Hz); 6.45 (d, 1H, $\mathrm{J} 1=15.7 \mathrm{~Hz}) ; 4.72(\mathrm{dd}, 1 \mathrm{H}, \mathrm{J} 1=7.8 \mathrm{~Hz}, \mathrm{~J} 2=4.9 \mathrm{~Hz}) ; 3.84(\mathrm{~s}, 3 \mathrm{H}) ; 3.54(\mathrm{dd}, 1 \mathrm{H}$, $\mathrm{J} 1=13.4 \mathrm{~Hz}, \mathrm{~J} 2=4.9 \mathrm{~Hz}) ; 3.44(\mathrm{dd}, 1 \mathrm{H}, \mathrm{J} 1=13.7 \mathrm{~Hz}, \mathrm{~J} 2=7.9 \mathrm{~Hz})$. 
NMR ${ }^{13} \mathbf{C}\left(\mathrm{CD}_{3} \mathrm{OD}\right) \delta \mathrm{ppm:}$

$169.4 ; 158.1 ; 149.8 ; 149.2 ; 142.2 ; 134.7 ; 128.4 ; 128.2 ; 123.3 ; 118.6 ; 116.4$;

$116.1 ; 111.5 ; 73.4 ; 56.3 ; 48.3$.

$\mathbf{R}_{f}=22 \mathrm{~mm} / 50 \mathrm{~mm}($ EtOAc $/$ Hexanes $=75 / 25)$; amorphous crystals

MS (FAB): $330.1(\mathrm{M}+1)$

HRMS (FAB): $330.1338\left(\mathrm{C}_{18} \mathrm{H}_{20} \mathrm{NO}_{5}, \mathrm{M}+1\right.$; calc. 330.134148$)$

MS (ESI) (m/z): 712.02(16.97), 329.81(M+1, 98.90), 312.02(M-17, 100.00)

UV (PDA; $\left.\lambda_{\max }, \mathrm{nm}\right): 230,295,320$;

\section{Procedure for parallel synthesis of combinatorial library:}

PS-carbodiimide beads (Argonaut Technologies Inc., $110 \mu \mathrm{m}, 1.37 \mathrm{mmol} / \mathrm{g}$ ) were loaded (using the bead loading block; see Figure S2) into 96 deep well plate (well volume $1 \mathrm{~mL}, 22$ $\mathrm{mg} / \mathrm{well}, 0.03 \mathrm{~mol} / \mathrm{well}$, see Figure S2) and suspended in freshly distilled THF $(0.25 \mathrm{~mL} / \mathrm{well})$. Solutions of corresponding acid building blocks A-H $(0.3 \mathrm{~mL}, 0.0153 \mathrm{mmol} / \mathrm{well})$ were added in each column, followed by solutions of corresponding amine building blocks 8-18 $(0.3 \mathrm{~mL}, 0.015$ $\mathrm{mmol} / \mathrm{well}$ ) added to each row. The 96-well plate was capped with a Teflon lid and rotated (60$80 \mathrm{rpm}$ ) for $48 \mathrm{~h}$ on a mechanical stirrer so that the beads are freely moving in the solution. Upon completion the beads were filtered off (through a Pasteur pipettes fitted with a cotton plug) and washed with THF ( $3 \times 0.3 \mathrm{~mL})$. Removal of the solvent in vacuo afforded amide products in $85 \%$ average yield. The library was analyzed by TLC and LC-MS. LC-MS was conducted on all 88 members of the library using a reversed-phase $\mathrm{C} 18$ column, acetonitrile $/ \mathrm{H}_{2} \mathrm{O}$ containing $0.1 \%$ formic acid. Two representative LC-MS analyses are shown in Figure S1, below. The mass spectrometer was a Finnigan LCQ decaXP equipped with a Surveyor autosampler, a Surveyor PDA detector $(200-400 \mathrm{~nm})$ and a mass selective detector. The purity of each compound in the library, and the mass observed for each compound in the library is listed in the Table S3, below. Table S4 list the purity data alone. 
Figure S1. Representative LC/MS analysis of 2 compounds from the library.
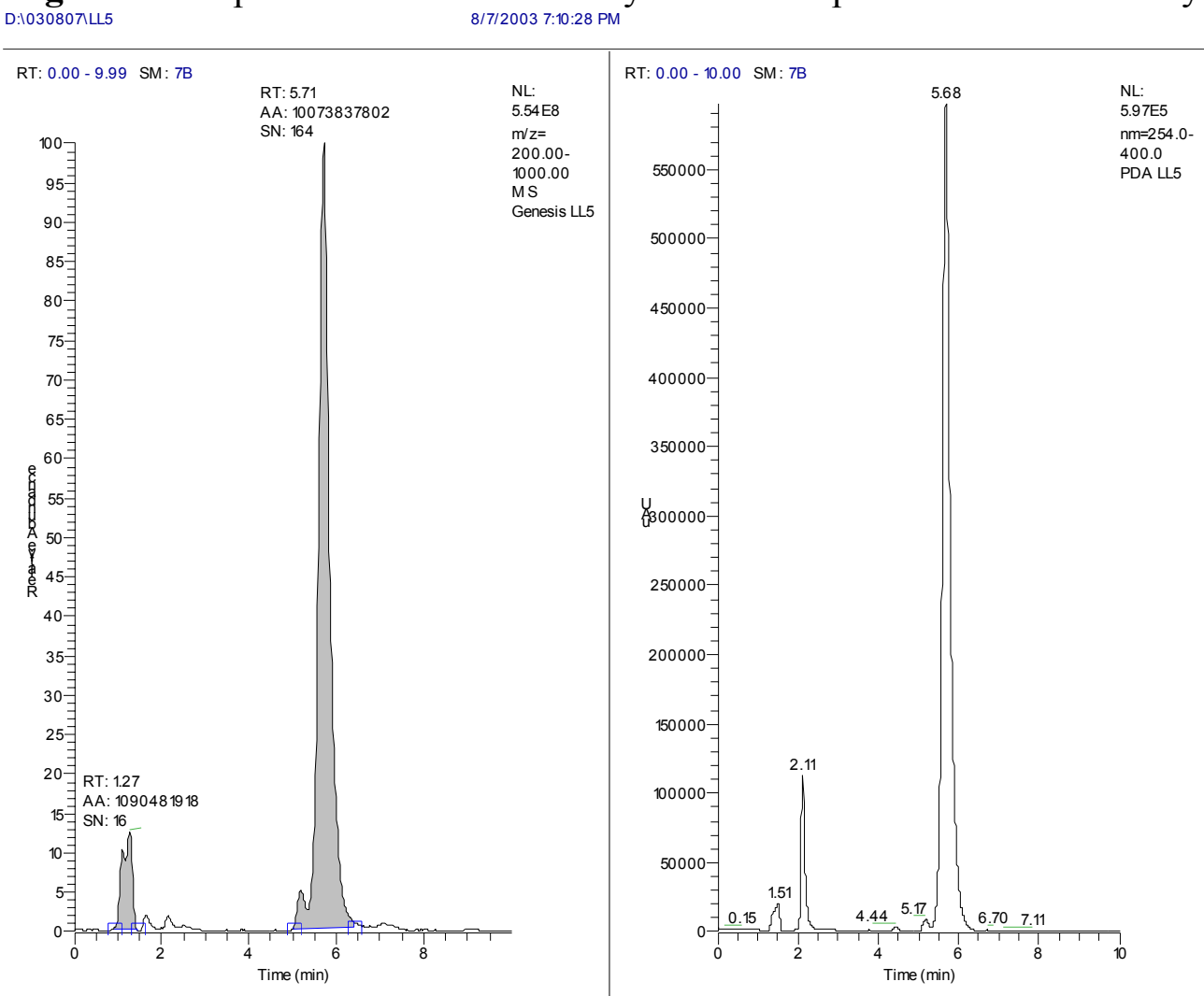

LL5\#363-380 RT: 5.62-5.84 AV: 18 SB: $11.96 \quad$ NL: 1.8 1E 8 T: + c ESI Full ms [ 200.00-1000.00]

LL5\# 1719 RT: 5.73 AV: 1 SB: 10.42 NL: 1.05E6 microAU
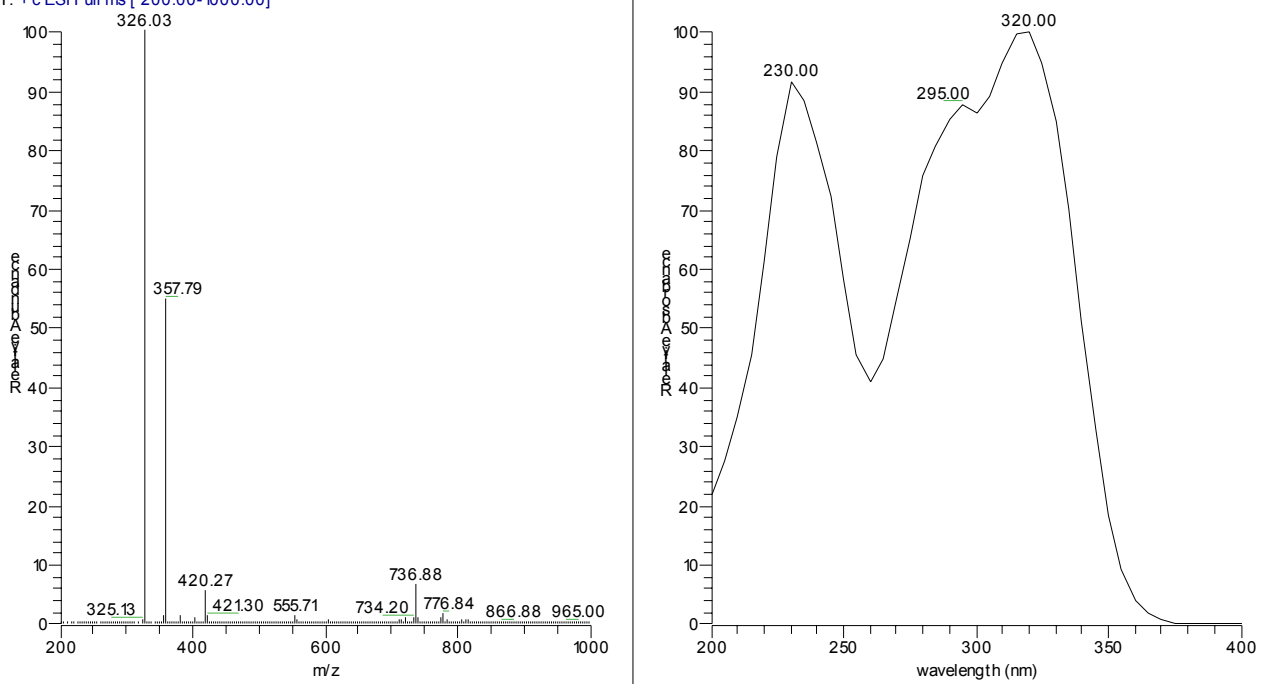


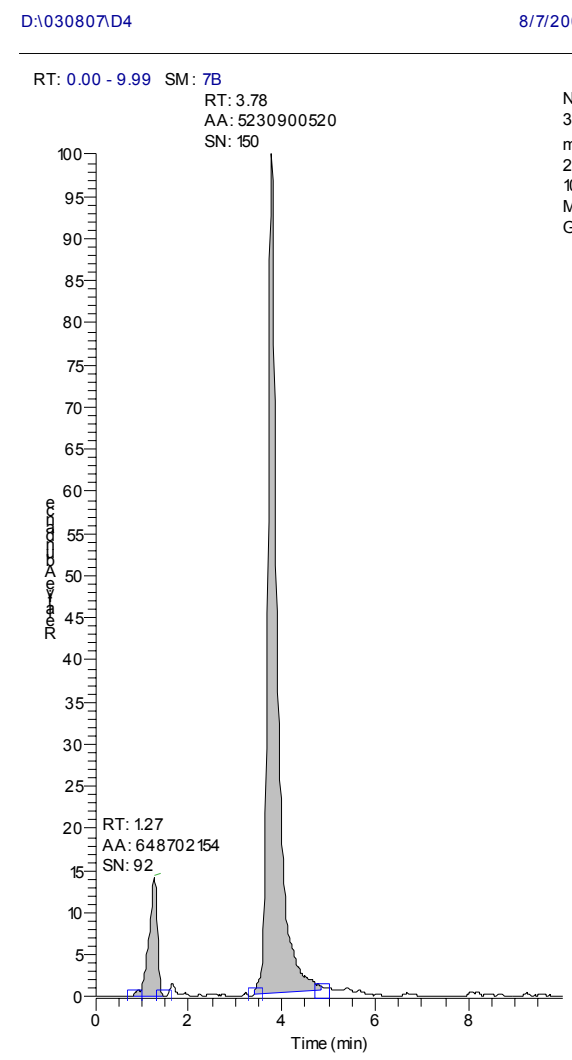

/72003 9:27:32 PM
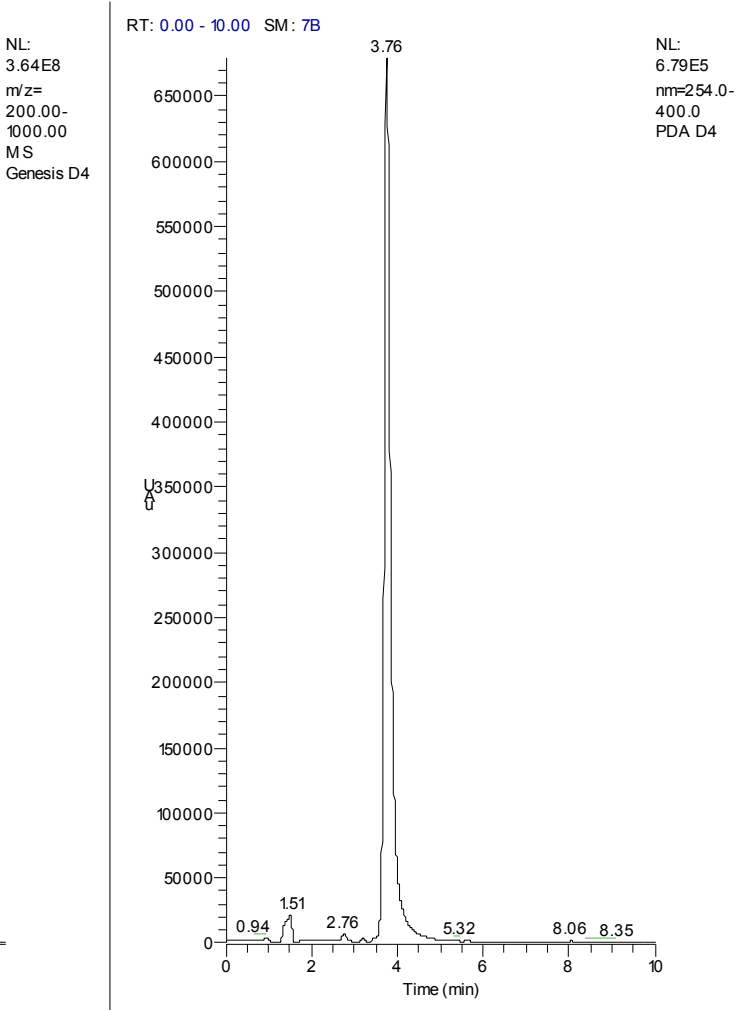

D4 \#245 RT: 3.79 AV: 1 SB: 11.99 NL: $2.07 E 8$ T: + c ESI Full ms [ 200.00-1000.00]

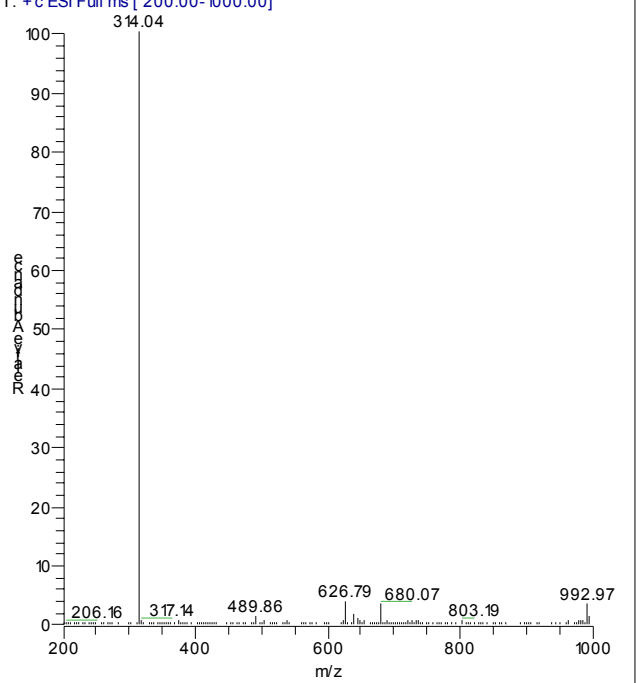

D4 \#1137 RT: 3.79 AV: 1 SB: 10.42 NL: 1.16E6 microAU

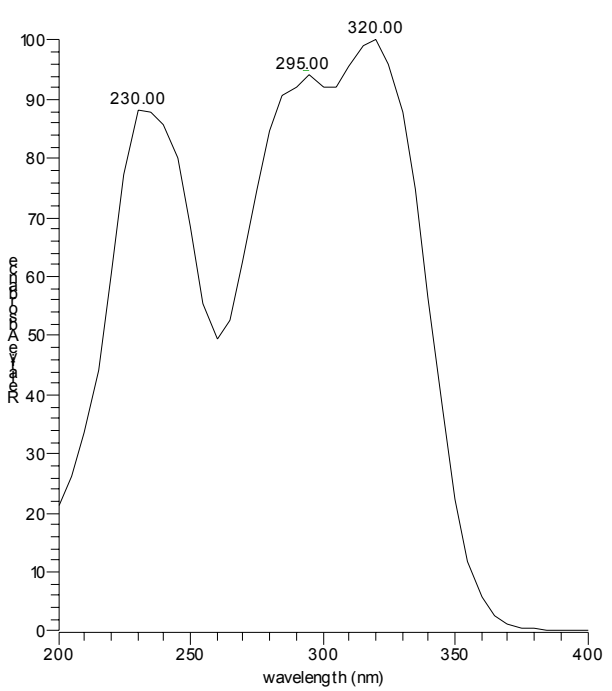


Table S3. Characterization of library members.

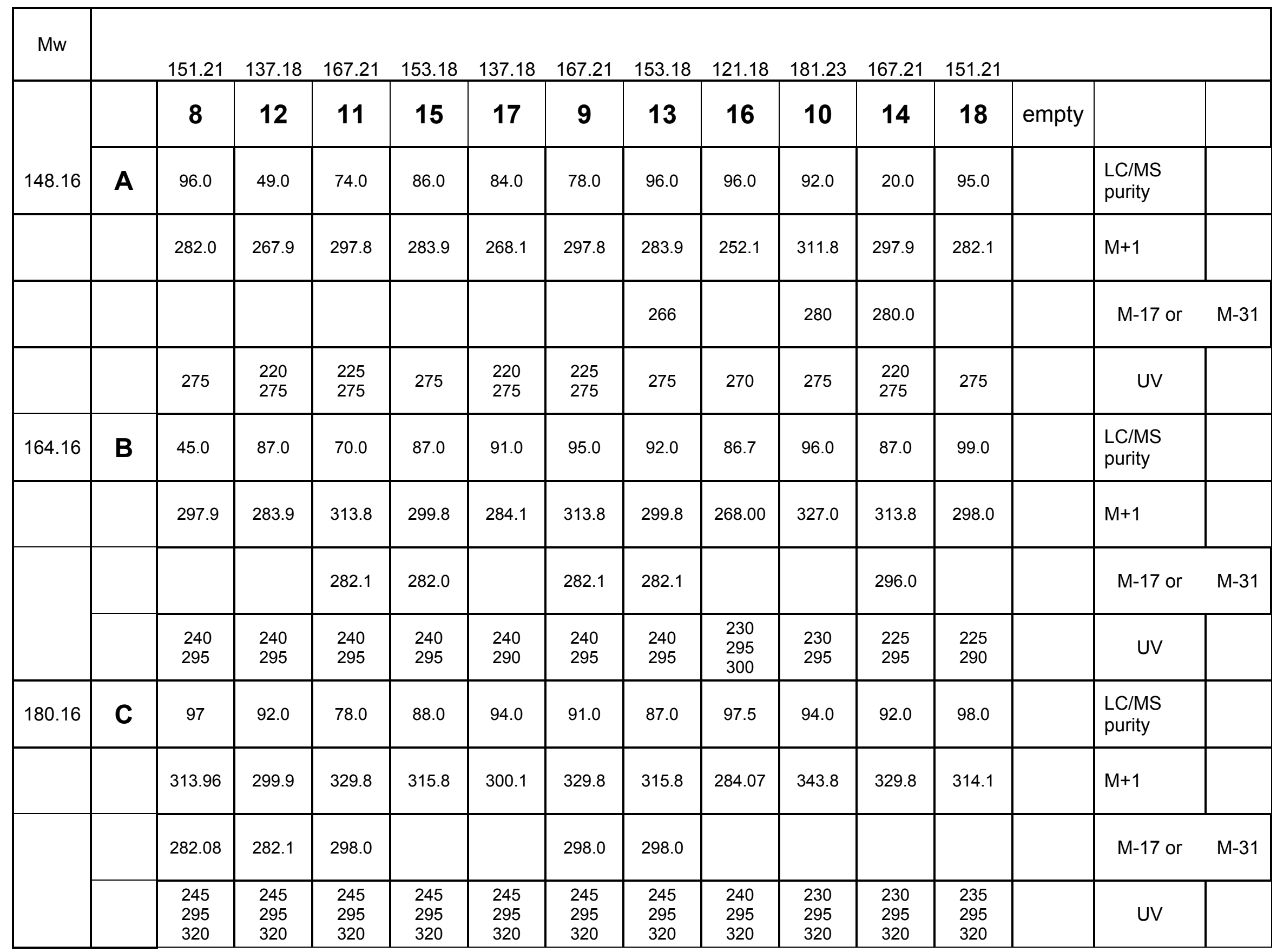


Table S3. Characterization of library members (continued).

\begin{tabular}{|c|c|c|c|c|c|c|c|c|c|c|c|c|c|c|}
\hline 194.18 & D & 59.0 & 94.0 & 76.0 & 94.0 & 93.0 & 94.0 & 95.0 & 95.7 & 83.0 & 94.0 & 97.0 & $\begin{array}{l}\text { LC/MS } \\
\text { purity }\end{array}$ & \\
\hline & & 327.4 & 313.9 & 343.8 & 329.8 & 314.1 & 343.8 & 329.8 & 298.1 & 357.8 & 343.8 & 328.1 & $M+1$ & \\
\hline & & & 296.1 & 312.0 & 312.1 & & 312.0 & 312.1 & & & 326.7 & & $\mathrm{M}-17$ or & M-31 \\
\hline & & $\begin{array}{l}235 \\
295 \\
320\end{array}$ & $\begin{array}{l}245 \\
295 \\
320\end{array}$ & $\begin{array}{l}245 \\
295 \\
320\end{array}$ & $\begin{array}{l}245 \\
295 \\
320\end{array}$ & $\begin{array}{l}245 \\
295 \\
320\end{array}$ & $\begin{array}{l}245 \\
295 \\
320\end{array}$ & $\begin{array}{l}245 \\
295 \\
320\end{array}$ & $\begin{array}{l}235 \\
295 \\
315\end{array}$ & $\begin{array}{l}230 \\
295 \\
320\end{array}$ & $\begin{array}{l}230 \\
295 \\
320\end{array}$ & $\begin{array}{l}230 \\
295 \\
320\end{array}$ & UV & \\
\hline \multirow[t]{4}{*}{194.18} & E & 87.0 & 82.0 & 93.0 & 81.0 & 79.0 & 85.0 & 85.0 & 70.6 & 86.0 & 64.0 & 82.0 & $\begin{array}{l}\text { LC/MS } \\
\text { purity }\end{array}$ & \\
\hline & & 328.0 & 314.0 & 343.9 & 329.9 & 314.1 & 343.9 & 329.9 & 298.1 & 357.0 & 326.0 & 328.0 & $M+1$ & \\
\hline & & & 296.1 & 312.0 & 312.1 & & 312.1 & & & & 310.1 & & M-17 or & M-31 \\
\hline & & $\begin{array}{l}240 \\
295 \\
320\end{array}$ & $\begin{array}{l}245 \\
295 \\
320\end{array}$ & $\begin{array}{l}245 \\
295 \\
320\end{array}$ & $\begin{array}{l}245 \\
290 \\
320\end{array}$ & $\begin{array}{l}245 \\
290 \\
320\end{array}$ & $\begin{array}{l}245 \\
295 \\
320\end{array}$ & $\begin{array}{l}245 \\
295 \\
320\end{array}$ & $\begin{array}{l}240 \\
290 \\
320\end{array}$ & $\begin{array}{l}230 \\
290 \\
320\end{array}$ & $\begin{array}{l}240 \\
280 \\
320\end{array}$ & $\begin{array}{l}225 \\
290 \\
320\end{array}$ & UV & \\
\hline \multirow[t]{4}{*}{238.24} & $\mathbf{F}$ & 50.0 & 77.0 & 79.0 & 86.0 & 94.2 & 89.0 & 84.0 & 70.1 & 31.0 & 63.0 & 61.0 & $\begin{array}{l}\text { LC/MS } \\
\text { purity }\end{array}$ & \\
\hline & & 372.0 & 357.9 & 387.8 & 373.8 & 358.0 & 387.8 & 373.8 & 342.0 & 401.9 & 387.8 & 372.0 & $M+1$ & \\
\hline & & & & & 536.1 & & & 356.0 & & 370.0 & 370.0 & & $\mathrm{M}-17$ or & M-31 \\
\hline & & $\begin{array}{l}245 \\
295\end{array}$ & $\begin{array}{l}230 \\
300\end{array}$ & $\begin{array}{l}230 \\
300\end{array}$ & $\begin{array}{l}240 \\
300\end{array}$ & $\begin{array}{l}230 \\
300\end{array}$ & $\begin{array}{l}235 \\
300\end{array}$ & $\begin{array}{l}240 \\
300\end{array}$ & $\begin{array}{l}225 \\
275\end{array}$ & $\begin{array}{l}225 \\
275\end{array}$ & $\begin{array}{l}230 \\
300\end{array}$ & $\begin{array}{l}240 \\
300\end{array}$ & UV & \\
\hline 224.21 & $\mathbf{G}$ & 64.0 & 94.0 & 79.0 & 91.0 & 91.0 & 93.0 & 87.0 & 95.0 & 92.0 & 93.0 & 94.0 & $\begin{array}{l}\text { LC/MS } \\
\text { purity }\end{array}$ & \\
\hline
\end{tabular}


Table S3. Characterization of library members (continued).

\begin{tabular}{|c|c|c|c|c|c|c|c|c|c|c|c|c|c|c|}
\hline & & 358.0 & 343.9 & 373.9 & 359.8 & 344.0 & 373.9 & 359.8 & 328.0 & 387.8 & 373.8 & 358.1 & $M+1$ & \\
\hline & & & 326.1 & 342.1 & 342.0 & & 342.0 & & & & 356 & & $\mathrm{M}-17$ or & M-31 \\
\hline & & $\begin{array}{l}240 \\
320\end{array}$ & $\begin{array}{l}245 \\
320\end{array}$ & $\begin{array}{l}245 \\
320\end{array}$ & $\begin{array}{l}245 \\
320\end{array}$ & $\begin{array}{l}245 \\
320\end{array}$ & $\begin{array}{l}245 \\
320\end{array}$ & $\begin{array}{l}245 \\
320\end{array}$ & $\begin{array}{l}240 \\
320\end{array}$ & $\begin{array}{l}240 \\
320\end{array}$ & $\begin{array}{l}240 \\
320\end{array}$ & $\begin{array}{l}235 \\
320\end{array}$ & UV & \\
\hline \multirow[t]{4}{*}{178.18} & H & 92.0 & 87.0 & 76.0 & 81.0 & 74.0 & 87.0 & 96.0 & 90.0 & 91.0 & 10.0 & 82.0 & $\begin{array}{l}\text { LC/MS } \\
\text { purity }\end{array}$ & \\
\hline & & 311.9 & 297.9 & 327.8 & 313.8 & 298.0 & 327.8 & 313.8 & 282.1 & 341.8 & 327.8 & 312.1 & $M+1$ & \\
\hline & & & & & 296.0 & & & & & 310.0 & 310.0 & & M-17 or & M-31 \\
\hline & & $\begin{array}{l}240 \\
275\end{array}$ & $\begin{array}{l}230 \\
275\end{array}$ & $\begin{array}{l}230 \\
275\end{array}$ & 275.0 & $\begin{array}{l}225 \\
275\end{array}$ & $\begin{array}{l}230 \\
275\end{array}$ & $\begin{array}{l}240 \\
275\end{array}$ & 275 & 275 & 275 & 275 & UV & \\
\hline
\end{tabular}


Table S4. Purity of the library members as assessed by LC-MS.

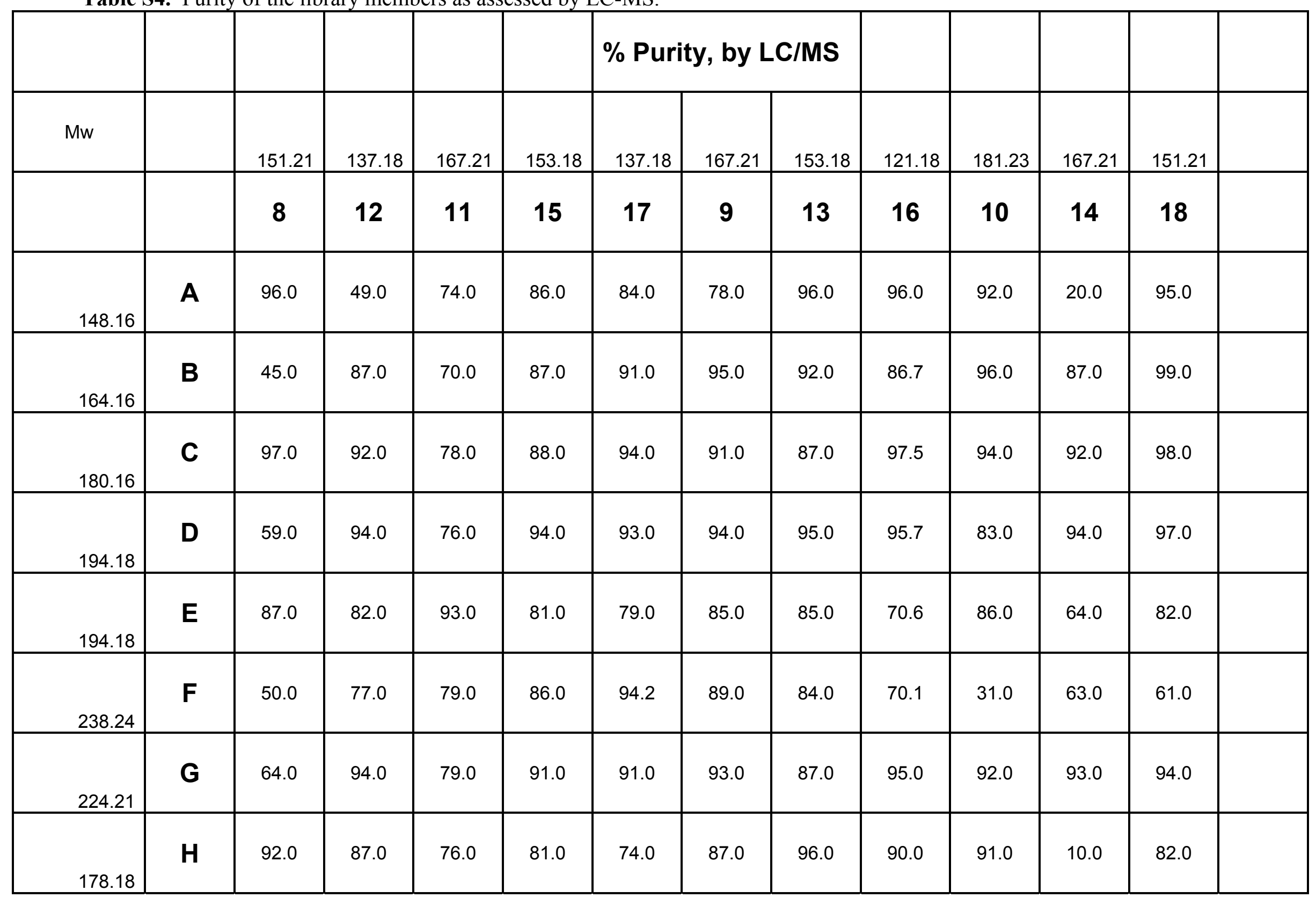




\section{Structures of ligands for $\mathrm{AA}$ reaction}

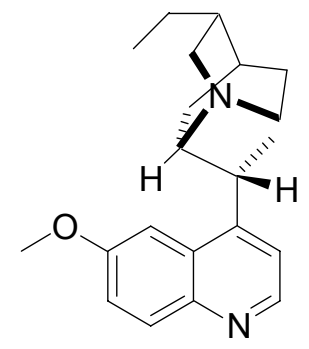

Dihydroquinyl(DHQ)

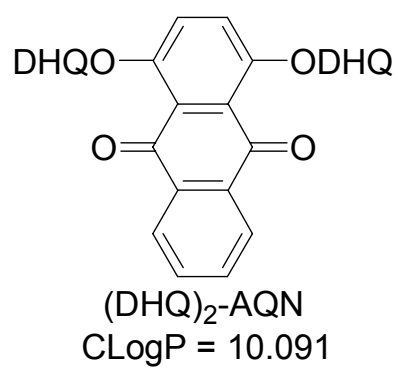

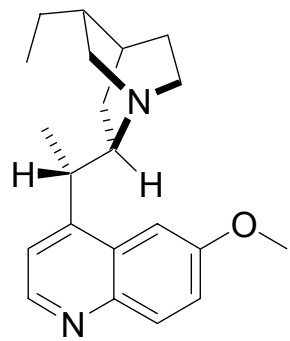

Dihydroquinidyl(DHQD)

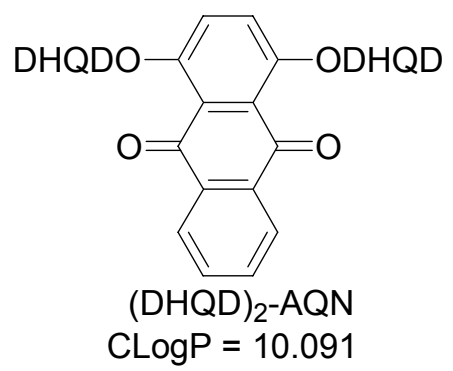<smiles>CCCOc1ccc(O)cc1</smiles>

(7) 
Figure S2. Apparatus for parallel synthesis. The devices below were constructed in the machine shop housed in the School of Chemical Sciences, at the University of Illinois, Urbana-Champaign.

Use of Loading Plate, 96 deep-well plate with tubes, and Lid: The Loading Plate was used to deliver a defined amount of beads to each well of the deep-well synthesis tubes. The PS-CDI beads were poured over the Loading Plate, the excess was scrapped off, and the holes were then aligned with the holes of the 96-deep-well plate with tubes. Simple inversion (followed by gentle tapping) delivered the beads into the wells. After loading the appropriate acids and amines, the Lid was placed onto the tubes and the entire apparatus was connected to an overhead stirrer for rotation.

1. Loading Plate: made in the 96 well format from aluminum, each well $(3 \times 6 \mathrm{~mm})$ delivers 10.8 $11.3 \mathrm{mg}$ of PS-CDI beads.
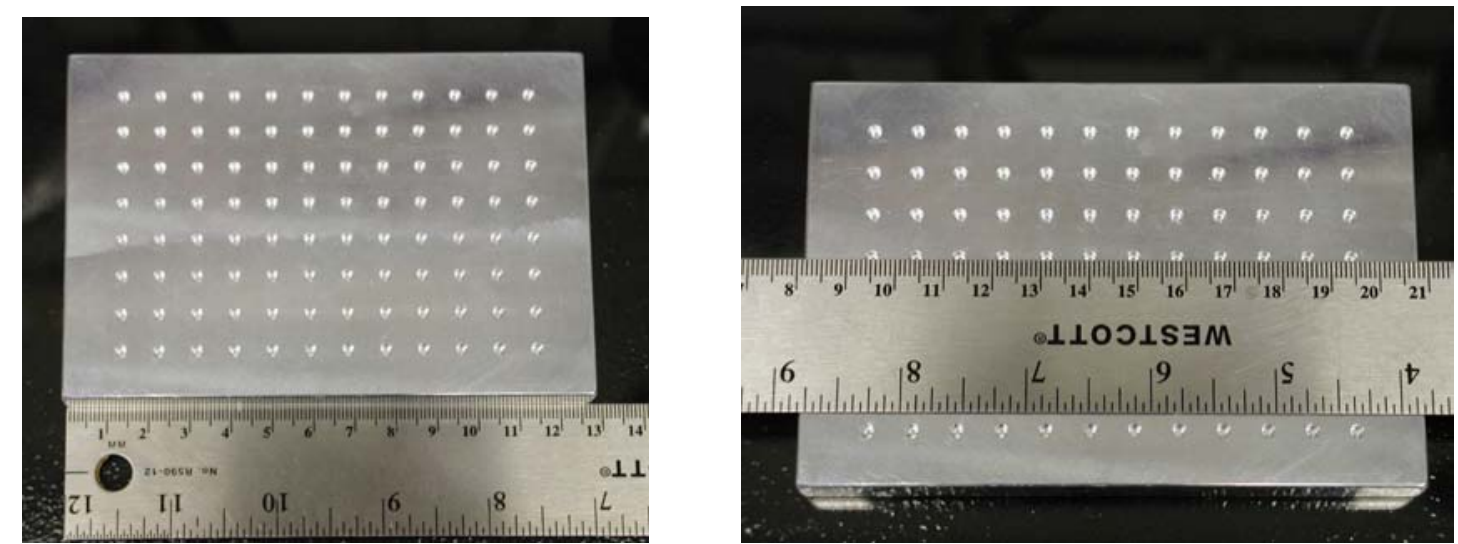

2. Positioning plate and 96 deep-well plate: made in the 96 well format from Teflon, holes 4.95 $\mathrm{mm}$ diameter, accommodates 6x50 mm glass inserts, Fisher Scientific \#14958-A, volume 1ml)
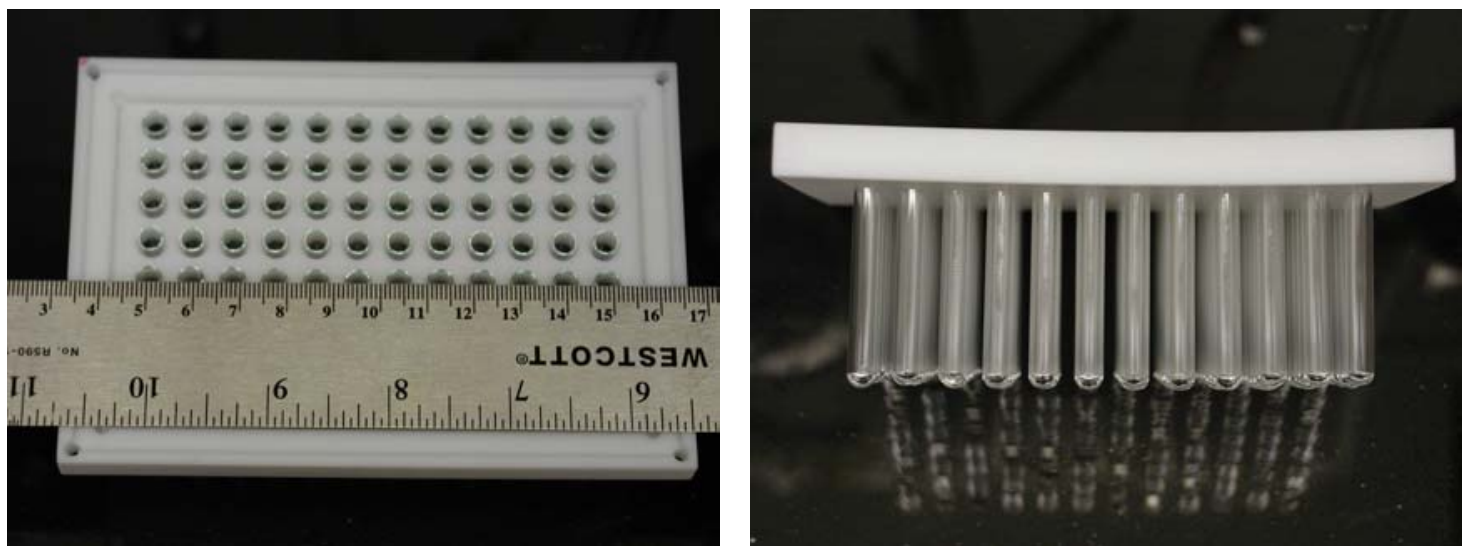

3. Lid: made in the 96 well format from Teflon, allows tightly seal the glass inserts to assure no leaking from the insert. 

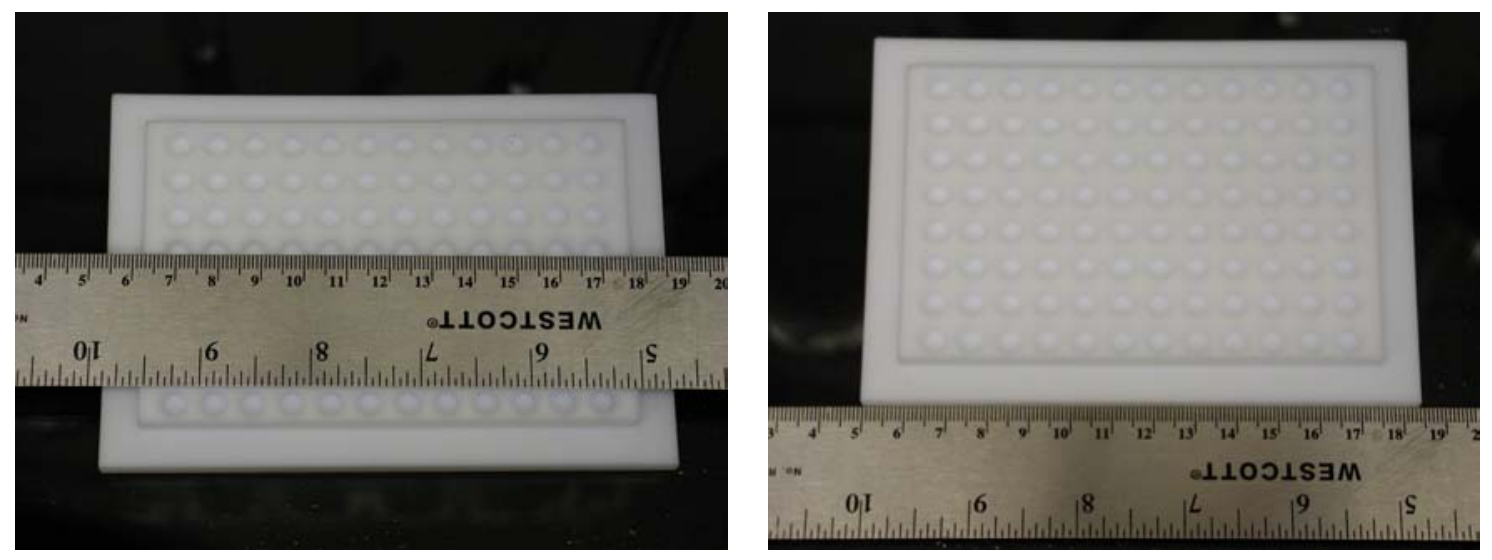


\section{Protocols for Biological Assays}

\section{General Cell Culture Conditions:}

U-937 and HL-60 cell lines were grown in RPMI 1640 supplemented with 10\% FBS and incubated at $37{ }^{\circ} \mathrm{C}$ in a $5 \% \mathrm{CO}_{2}, 95 \%$ air atmosphere and were split every two to three days as necessary.

\section{High-throughput Cell Death Assay on Library Members:}

U-937 and HL-60 cells from cell culture were harvested by centrifugation at $250 \mathrm{x} \mathrm{g}$ for $5 \mathrm{~min}$. Cells were then resuspended in RPMI $1640+10 \%$ FBS, counted using a hemocytometer and diluted so that 20,000 cells were seeded into each well of a Corning 96-well flat bottom microtiter plate (Fisher, Chicago IL). Media was then added to bring the total volume of each well to $100 \mu \mathrm{L}$. Test compounds were transferred into the wells using a 96-pin transfer apparatus (V \& P Scientific, San Diego CA) that transfers $0.2 \mu \mathrm{L}$ of compound. The compounds were made up as $50 \mathrm{mM}$ stock solutions in EtOH, so one transfer gave a final concentration of $100 \mu \mathrm{M}$. Controls were performed in which only EtOH (containing no compound) was pin-transferred into wells containing cells. The cells were incubated with the compounds for 24 hours, and then cell death was quantitated. This quantitation was performed by addition of $20 \mu \mathrm{L}$ of the MTS/PMS CellTiter 96 Cell Proliferation Assay reagent (Promega, Madison WI) to each well. The plates were incubated at $37{ }^{\circ} \mathrm{C}$ for approximately one hour until the colored product formed and the absorbance was then measured at $490 \mathrm{~nm}$ in a Spectra Max Plus 384 plate reader (Molecular Devices, Sunnyvale CA).

\section{Determination of $\mathrm{IC}_{50}$ Values for 1, 12-D, 13-D, and 15-D}

U-937 and HL-60 cells from cell culture were harvested by centrifugation at $250 \mathrm{x} \mathrm{g}$ for $5 \mathrm{~min}$. Cells were then resuspended in RPMI $1640+10 \%$ FBS, counted using a hemocytometer and diluted so that 10,000 cells were seeded in to each well of a Corning 96-well flat bottom microtiter plate (Fisher, Chicago IL). Media was then added to bring the total volume of each well to $100 \mu \mathrm{L}$. Each compound was weighed and then diluted with $\mathrm{EtOH}$ to make a $100 \mathrm{mM}$ stock solution. The compounds were added at 9 or more different concentration in $1 \mu \mathrm{L}$ of EtOH. After a $72 \mathrm{~h}$ incubation $\left(37{ }^{\mathrm{O}} \mathrm{C}\right.$ in a $5 \%$ $\mathrm{CO}_{2}, 95 \%$ air atmosphere) cell death was quantitated by addition of $20 \mu \mathrm{L}$ of the MTS/PMS CellTiter 96 Cell Proliferation Assay reagent (Promega, Madison WI) to each well. The plates were incubated at 37 ${ }^{\mathrm{O}} \mathrm{C}$ for approximately 1 hour until the colored product formed and the absorbance was then measured at $490 \mathrm{~nm}$ in a Spectra Max Plus 384 plate reader (Molecular Devices, Sunnyvale CA). The $\mathrm{IC}_{50}$ was taken as the concentration that caused $50 \%$ cell death. The graphs used to determine the $\mathrm{IC}_{50}$ values are below: 

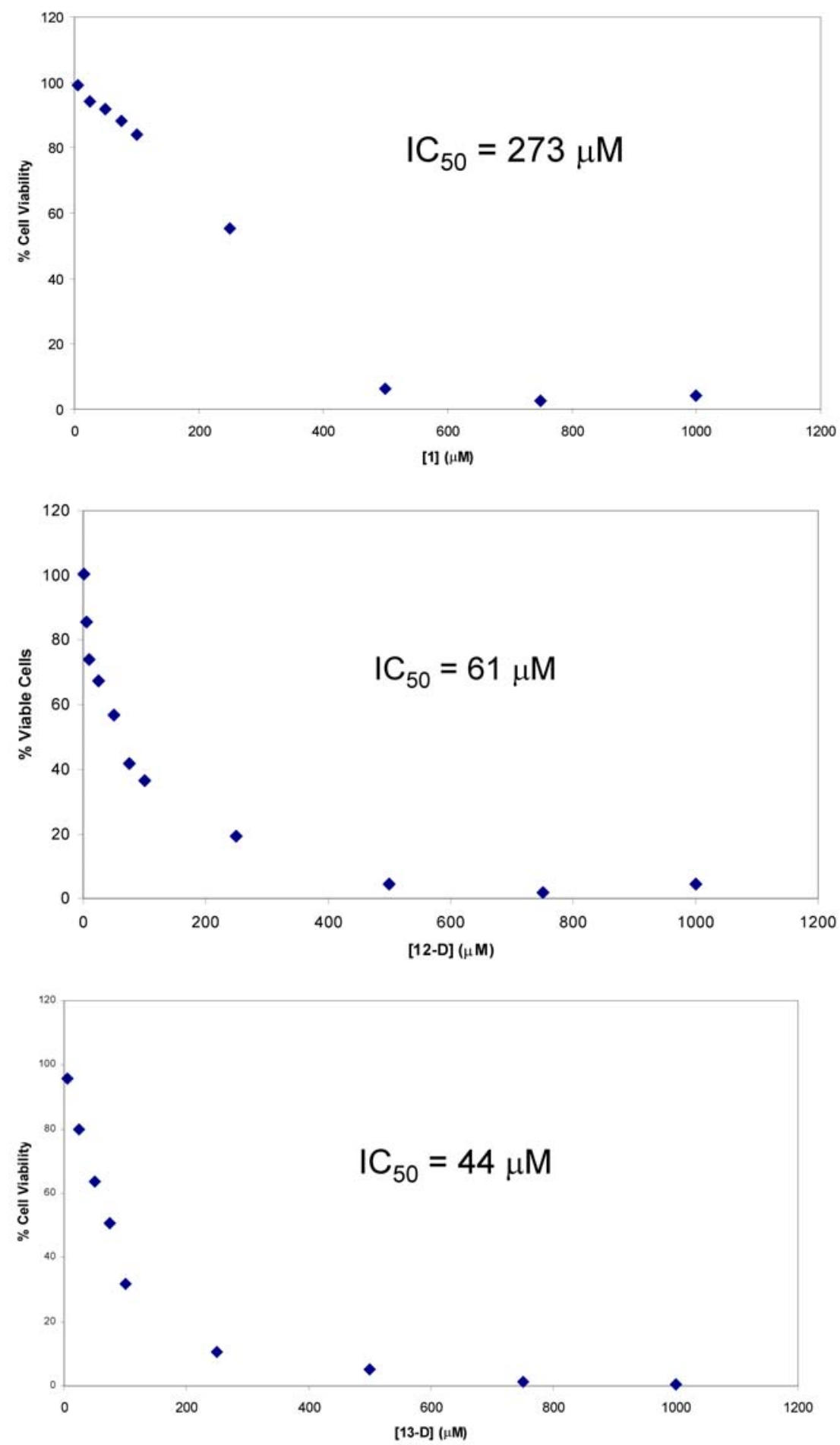


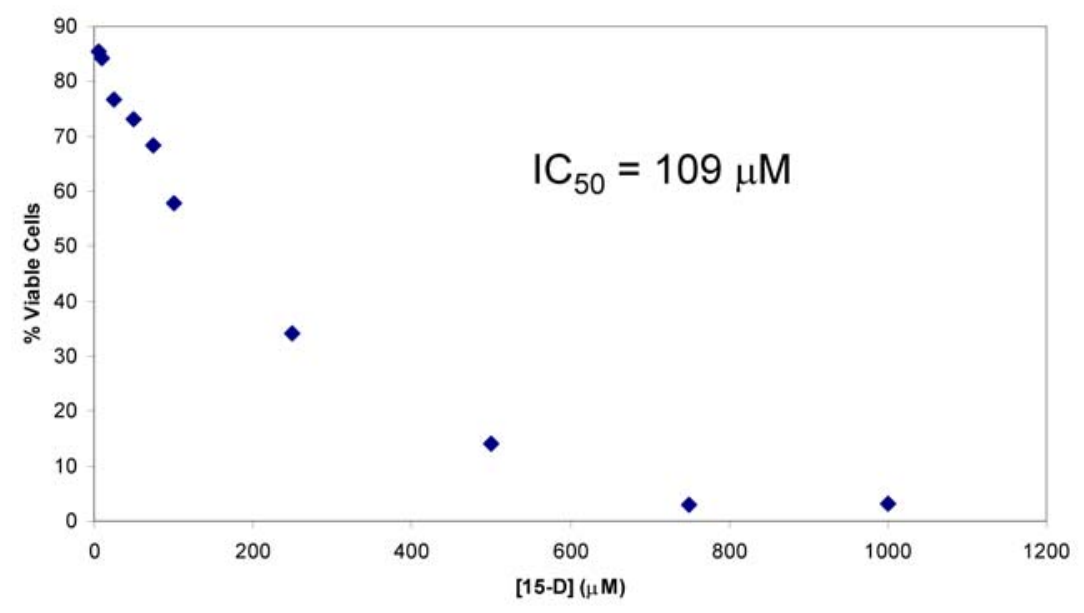

\section{Caspase-3 Activity Assay:}

The amount of caspase-3 like protease activity was determined by the amount of Ac-DEVDpNA ( $N$-acetyl-Asp-Glu-Val-Asp $p$-nitroanilide) cleaved per minute by cell lysates. To accomplish this, $100 \mu \mathrm{M}$ of 13-D was added to cell culture flasks containing $50 \mathrm{~mL}$ of $10 \times 10^{6} \mathrm{U}-937 \mathrm{cells} / \mathrm{mL}$ at 72,48 , 36, 24, 12 and 0 hours before harvesting. Cells were harvested by centrifugation, counted and diluted with RPMI 1640 media to a concentration of $4 \times 10^{6}$ cells $/ \mathrm{mL}$. $100 \mu \mathrm{L}$ of the diluted cells were added to the wells of a 96-well plate in quadruplicate. The plate was then spun at $1000 \mathrm{x} g$ for 5 minutes to pellet the cells. The cells were washed with $100 \mu \mathrm{L}$ of PBS $\left(137 \mathrm{mM} \mathrm{NaCl}, 2.7 \mathrm{mM} \mathrm{KCl}, 4.3 \mathrm{mM} \mathrm{Na}_{2} \mathrm{HPO}_{4}\right.$, $1.4 \mathrm{mM} \mathrm{KH}_{2} \mathrm{PO}_{4}, \mathrm{pH} 7.4$ ) and resuspended in $150 \mu \mathrm{L}$ of ice cold Caspase Assay Buffer (50mM HEPES, $100 \mathrm{mM} \mathrm{NaCl}, 10 \mathrm{mM}$ DTT, 0.1mM EDTA, 0.1\% CHAPS and 10\% Glycerol, pH 7.4). Each well was then sonicated to lyse the cells. $90 \mu \mathrm{L}$ of cell lysate was transferred from each well into a new plate. Caspase Assay Buffer was added to wells as a control. Ac-DEVD-pNA (Sigma, St. Louis MO) was added into each well to give a final concentration of $200 \mu \mathrm{M}$. The plate was then read every 2 minutes at $405 \mathrm{~nm}$ for 2 hours in a Spectra Max Plus 384 plate reader (Molecular Devices, Sunnyvale CA). The slope of the linear portion for each compound was then determined and any cleavage of the substrate in the control wells was subtracted out. The amount of Ac-DEVD-pNA cleaved in pmol/min was then calculated and plotted.

\section{Analysis of Mitochondria Depolarization by Flow Cytometry:}

The depolarization of the mitochondrial membrane was measured by the fluorescence emitted by the JC-9 dye (Molecular Probes, Eugene OR). $100 \mu \mathrm{M}$ of 13-D or $10 \mu \mathrm{M}$ etoposide in $1 \mu \mathrm{L}$ of EtOH were added to cell culture flasks containing $50 \mathrm{~mL}$ of $10 \times 10^{6} \mathrm{U}-937$ cells $/ \mathrm{mL}$. After growth for 72 hours $\left(37{ }^{\circ} \mathrm{C}\right.$ in a $5 \% \mathrm{CO}_{2}, 95 \%$ air atmosphere) the cells were harvested by centrifugation, counted, and diluted to $1 \times 10^{6}$ cells $/ \mathrm{mL}$ in RPMI 1640 media. $10 \mu \mathrm{g}$ of the JC-9 dye was added to $1 \times 10^{6}$ cells in 1 $\mathrm{mL}$ and incubated at room temperature for $10 \mathrm{~min}$. Cells were washed twice with PBS and resuspended in a final volume of $500 \mu \mathrm{L}$ PBS. The fluorescence intensity of each cell was determined by flow cytometry at 525nm (channel 1 green) and 675nm (channel $4 \mathrm{red}$ ). 50,000 cells were analyzed in each experiment. The data was then analyzed using Summit Software (Cytomation, Fort Collins CO) and the number of cells within the upper left region, viable cells, was determined. 


\section{Splenocyte Toxicity Assay:}

Splenocytes were isolated from the spleen of a 7-month old male C57Black/6 mouse and suspended in $1 \mathrm{~mL}$ RPMI $1640+10 \% \mathrm{FBS}+2.5 \mu \mathrm{g} / \mathrm{mL}$ concanavalin A. These cells were counted and diluted so that $2.5 \times 10^{5}$ cells were seeded in to each well containing a total of $200 \mu \mathrm{L}$ of media. Various concentrations of compound 13-D in $1 \mu \mathrm{L}$ of EtOH were added and the plates were then incubated at $37{ }^{\circ} \mathrm{C}$ in a $5 \% \mathrm{CO}_{2}, 95 \%$ air atmosphere for 72 hours. $1 \mu \mathrm{L}$ of EtOH was added to separate control wells. After 72 hours of incubation, $20 \mu \mathrm{L}$ of the MTS/PMS CellTiter 96 Cell Proliferation Assay reagent (Promega, Madison WI) was added to each well. The plates were incubated at $37{ }^{\mathrm{O}} \mathrm{C}$ for approximately two hours until the colored product formed and the absorbance was then measured at 490 $\mathrm{nm}$ in a Spectra Max Plus 384 plate reader (Molecular Devices, Sunnyvale CA).

\section{T-cell Isolation and Toxicity Assay:}

Splenocytes were isolated from the spleen of a 3-month old male C57Black/6 mouse and suspended in $1 \mathrm{~mL}$ RPMI $1640+10 \%$ FBS. Erythrocytes were selectively lysed and the T cells were highly enriched by using a mouse erythrocyte lysing kit and a mouse T cell enrichment column (R \& D Systems, Minneapolis MN). FITC labeled anti-TCR antibodies were used to determine the purity of T cells in pre- and post-column samples. The T cells were enriched from approximately $35 \%$ to $90 \%$ of the total cell population (see Figure S5, S6 below). The purified T cells were then counted and diluted so that $2.5 \times 10^{5}$ cells were seeded in to each well of a 96-well plate containing $200 \mu \mathrm{L}$ of media. These cells were either stimulated to grow (by addition of ConA to a concentration of $2.5 \mu \mathrm{g} / \mathrm{mL}$ ) or left untreated. Various concentrations of compound 13-D in $1 \mu \mathrm{L}$ of EtOH or $1 \mu \mathrm{L}$ of EtOH as a control were added and the plates were incubated at $37{ }^{\circ} \mathrm{C}$ in a $5 \% \mathrm{CO}_{2}, 95 \%$ air atmosphere for 72 hours. After the 72 hours of incubation, $200 \mu \mathrm{L}$ of cells were diluted in $300 \mu \mathrm{L}$ PBS. Propidium iodide was then added to a concentration of $1 \mu \mathrm{g} / \mathrm{mL}$. Cells were then incubated at room temperature for 5 minutes and analyzed by flow cytometry. The fluorescene intensity of each cell was determined at $620 \mathrm{~nm}$ (channel 3) and at least 50,000 cells were analyzed for each experiment (Figure S7, S8, below). The data was then analyzed using Summit Software (Cytomation, Fort Collins CO) and the number of viable cells was determined. Non-concanavalin A stimulated T cells were also treated with 13-D, and viable cells in these samples were determined by PI staining (as above). In both the ConA stimulated and nonstimulated experiments, no difference was observed between 13-D treated and non-treated control cells. 
Figure S5.

Pre-column T cells -- FITC labeled anti-TCR antibodies were used to determine the purity of T cells:

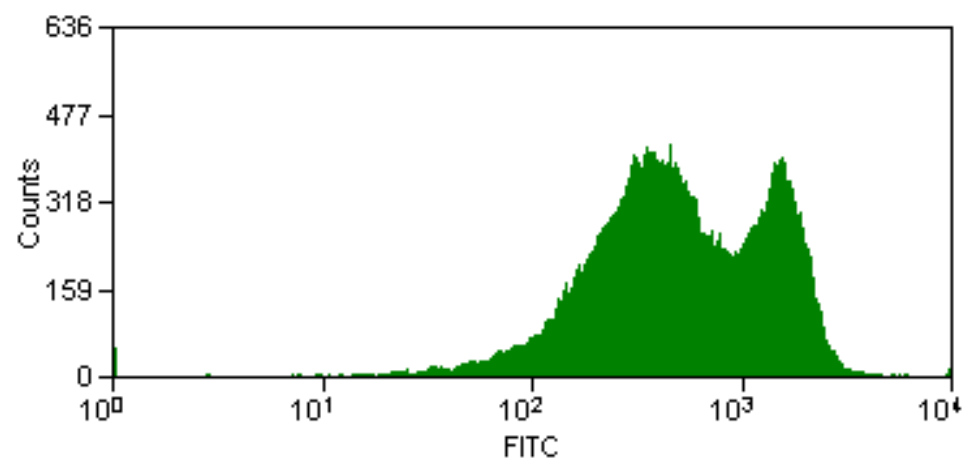

Figure S6.

Post-column T cells -- FITC labeled anti-TCR antibodies were used to determine the purity of T cells:

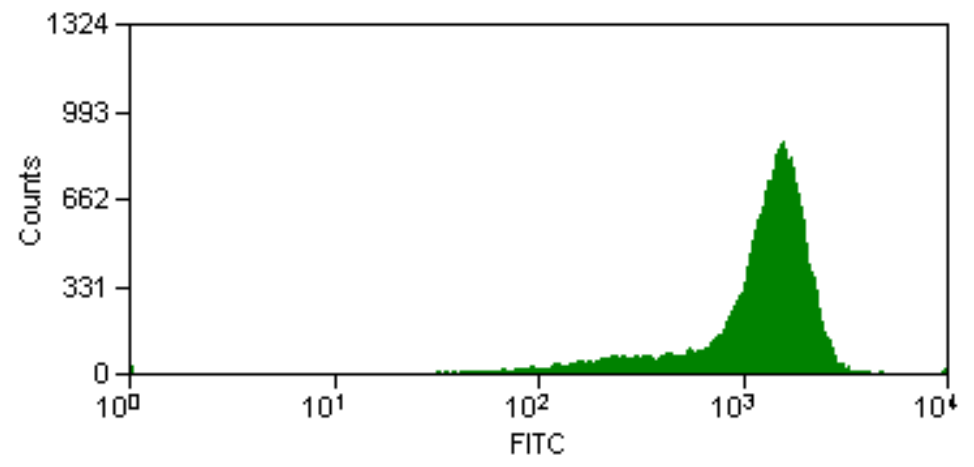


Figure 3B of the text is an overlay of Figures S7 and S8, below.

Figure S7.

Concanavalin A stimulated T cells:

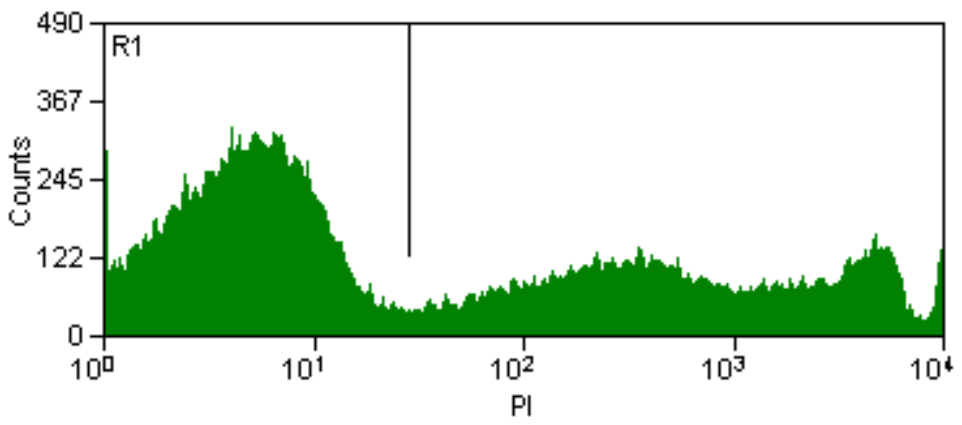

$\underline{\text { Viable Cells }(\mathrm{R} 1)=86.4 \%}$

Figure S8.

Concanavalin A stimulated T cells $+500 \mu \mathrm{M}$ 13-D:

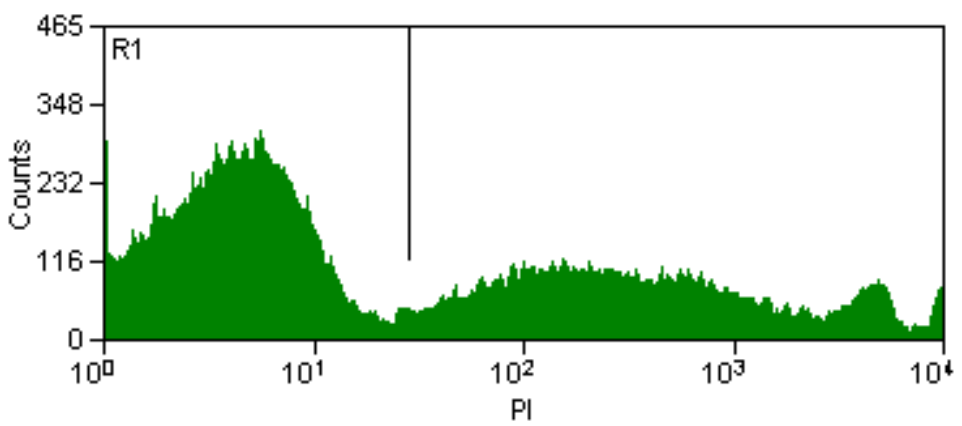

$\underline{\text { Viable Cells (R1) }=87.4 \%}$ 


\section{Microscopy:}

U-937 cells from cell culture were harvested by centrifugation at $250 \mathrm{xg}$ for 5 minutes. Cells were resuspended in RPMI $1640+10 \%$ FBS, counted using a hemocyometer and diluted so that 20,000 cells were seeded in to each well of a 96-well plate. Media was then added to bring the total volume of each well to $100 \mu \mathrm{L}$. Compound 13-D was added to make a final concentration of $100 \mu \mathrm{M}$. Pictures of the cells were taken at various times using a Carl Zeiss confocal microscope (Carl Zeiss, Thornwood NY).

Picture at 100x:

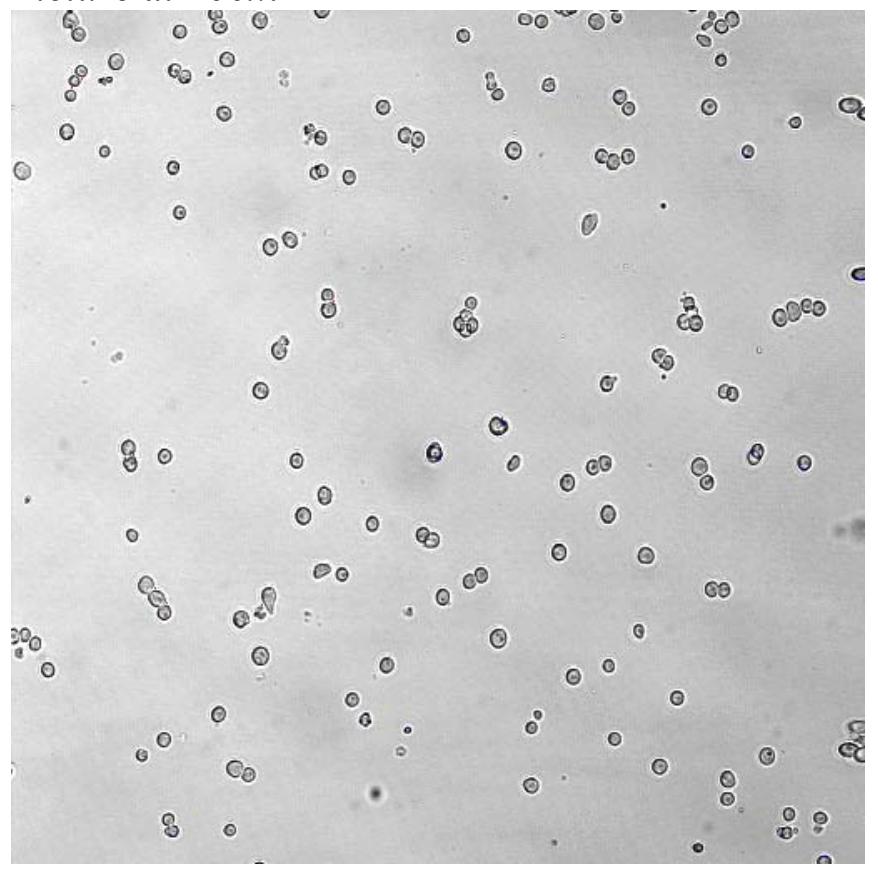


Picture at 100x:

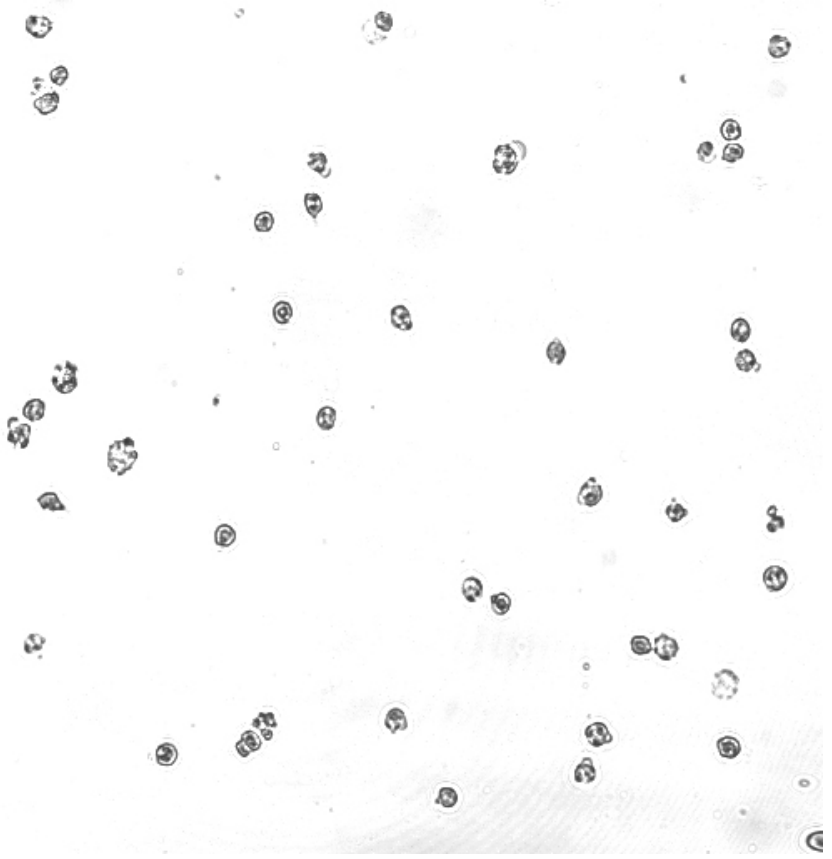

Picture at 400x:

(2)

(2) 驾 
Picture at 400x:

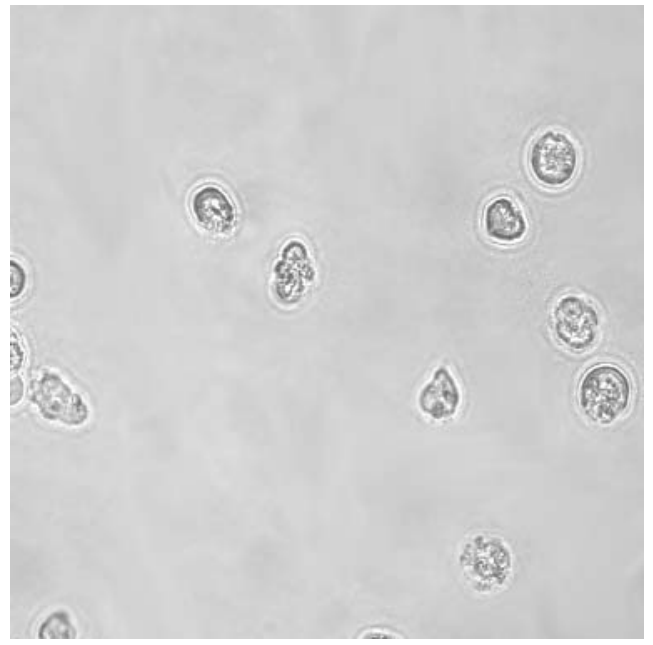

Picture at 400x:

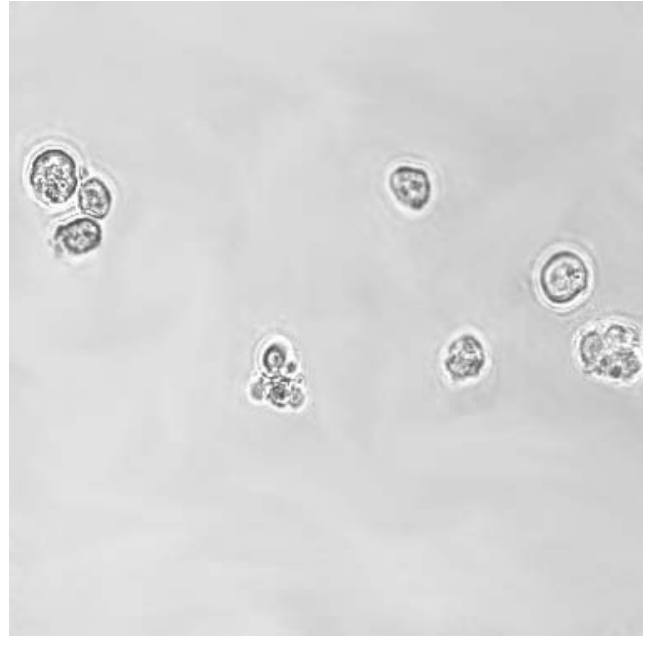


Picture at 200x:

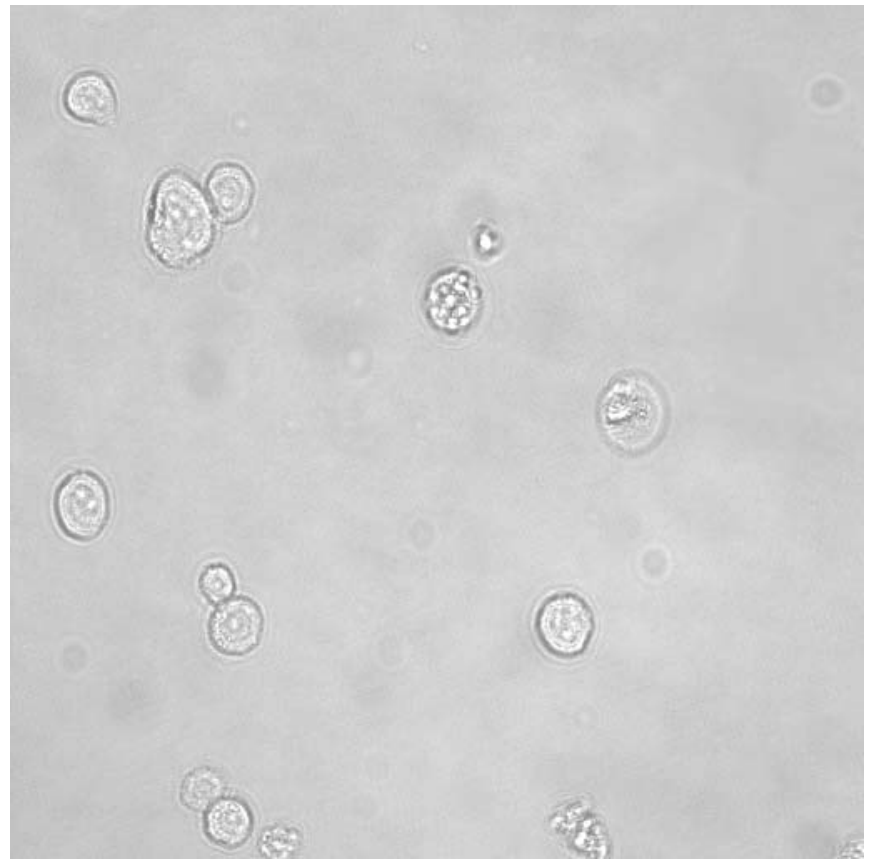




\section{References}

1. Nesterenko, V.; Byers, J. T.; Hergenrother, P. J. Org. Lett. 2003, 5, 281-284. 


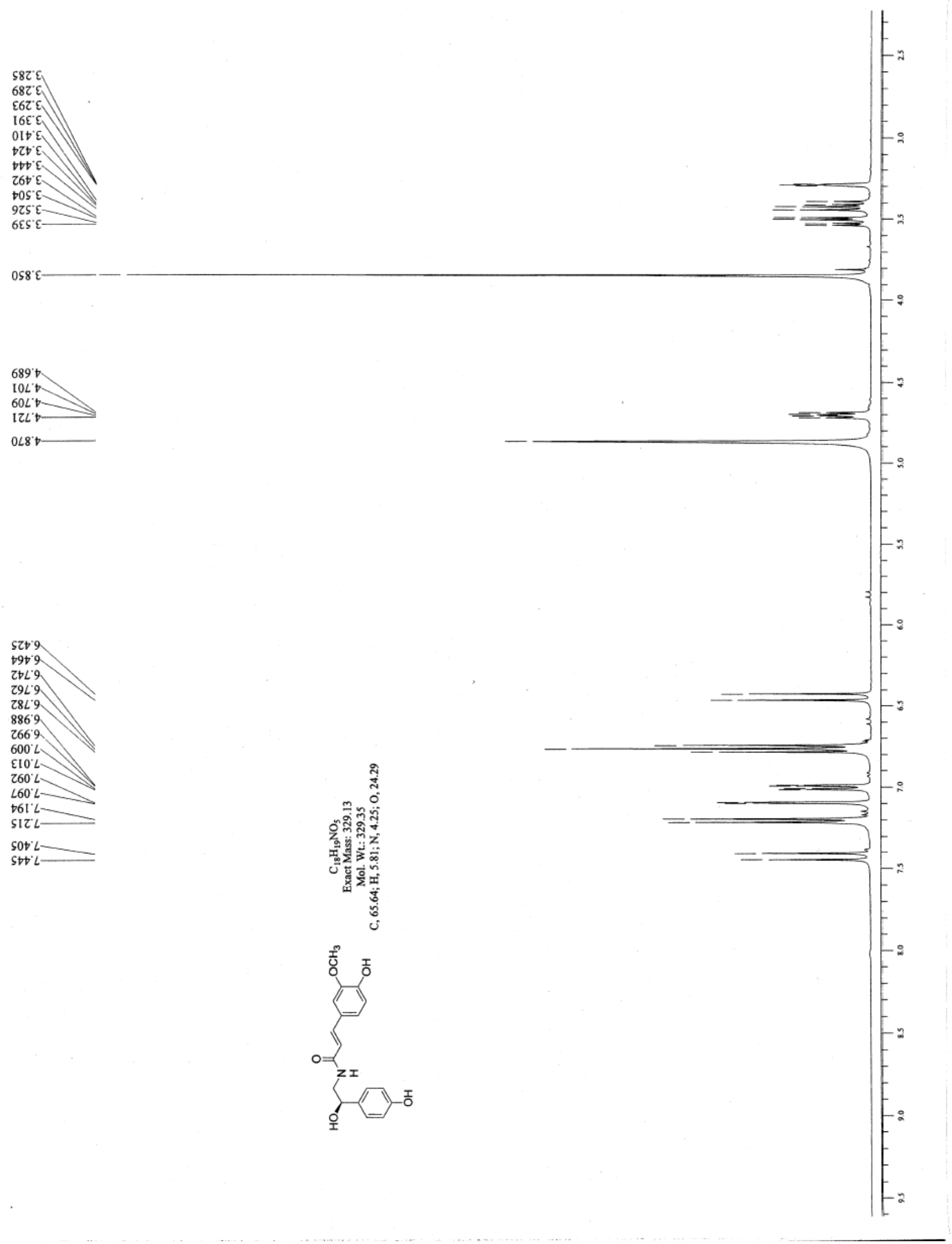




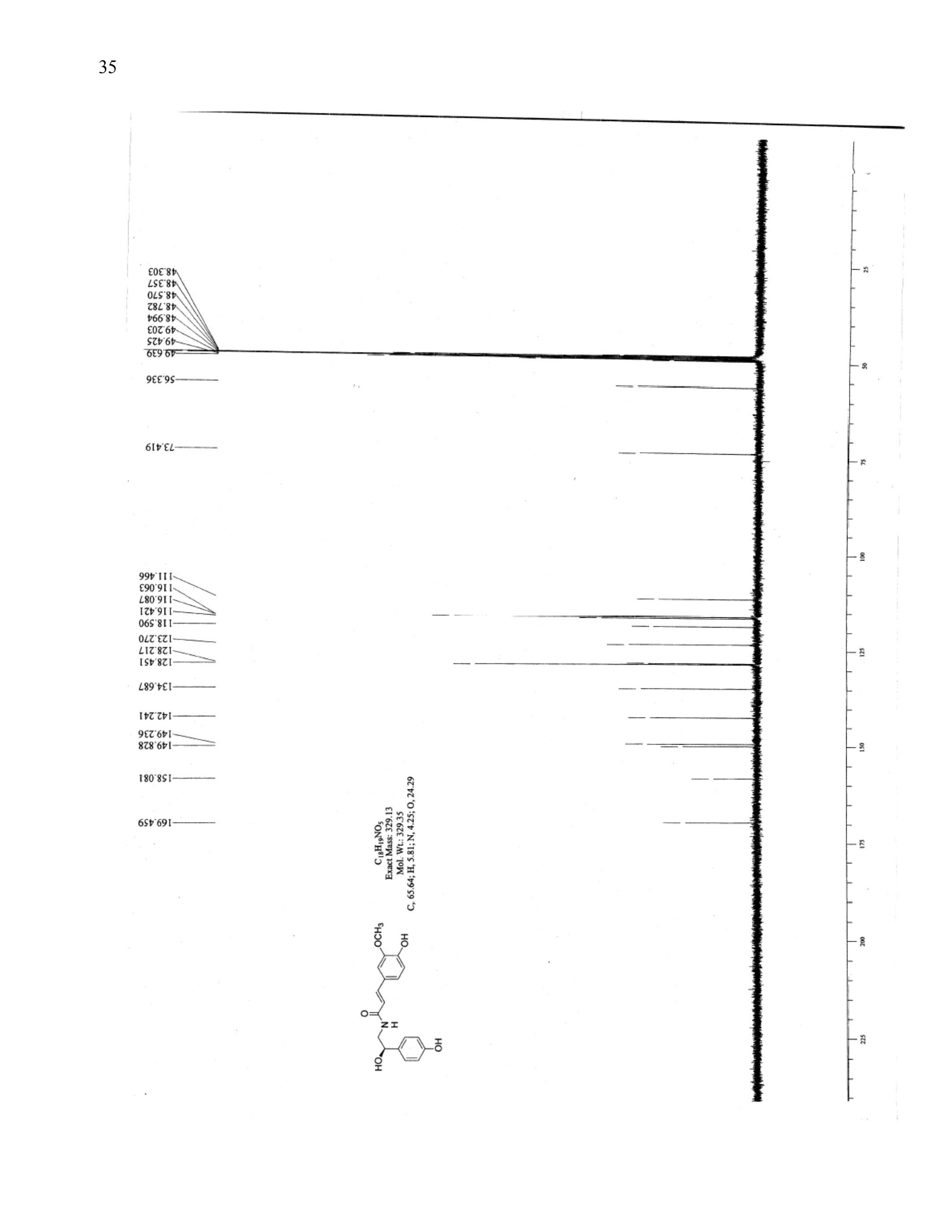




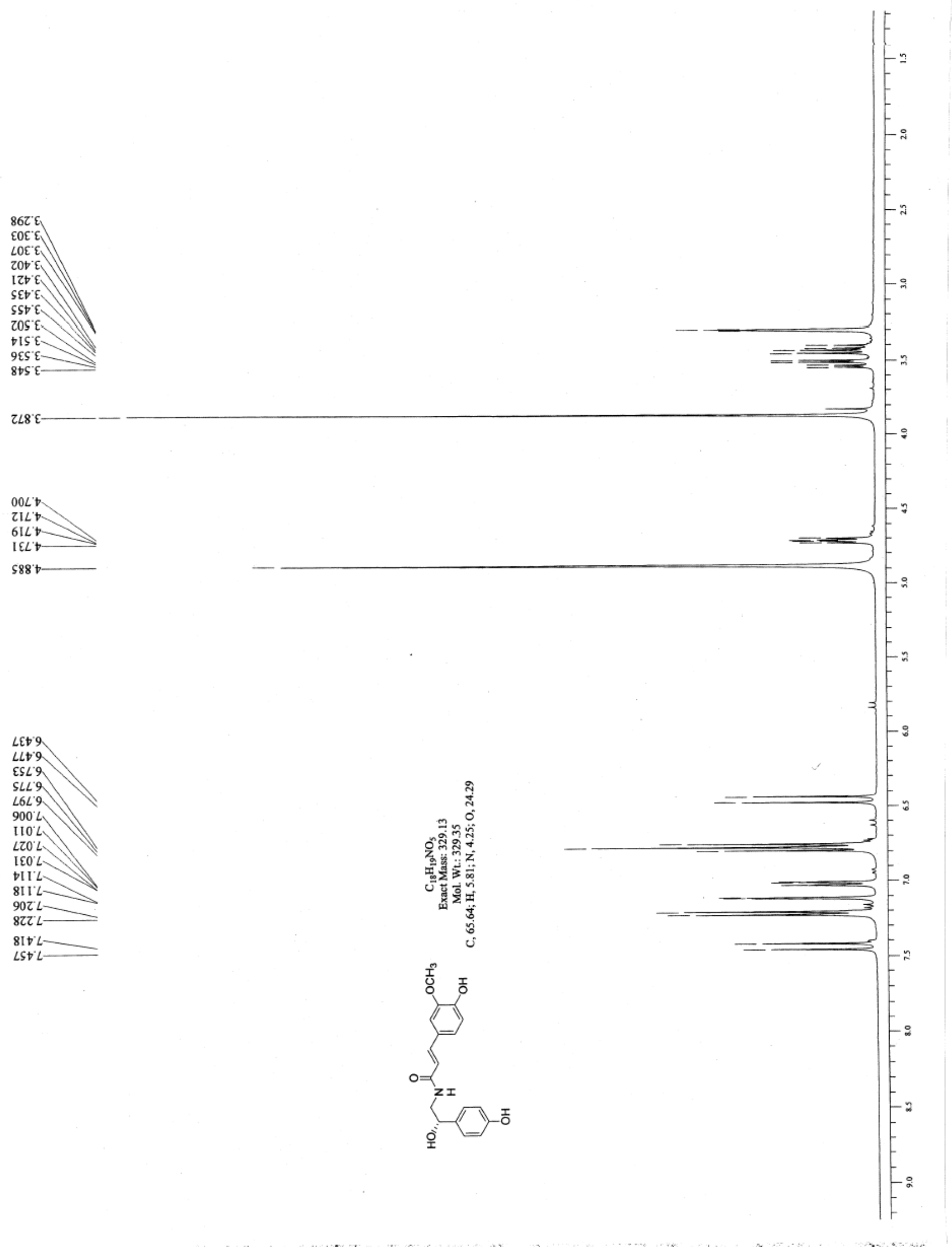


37

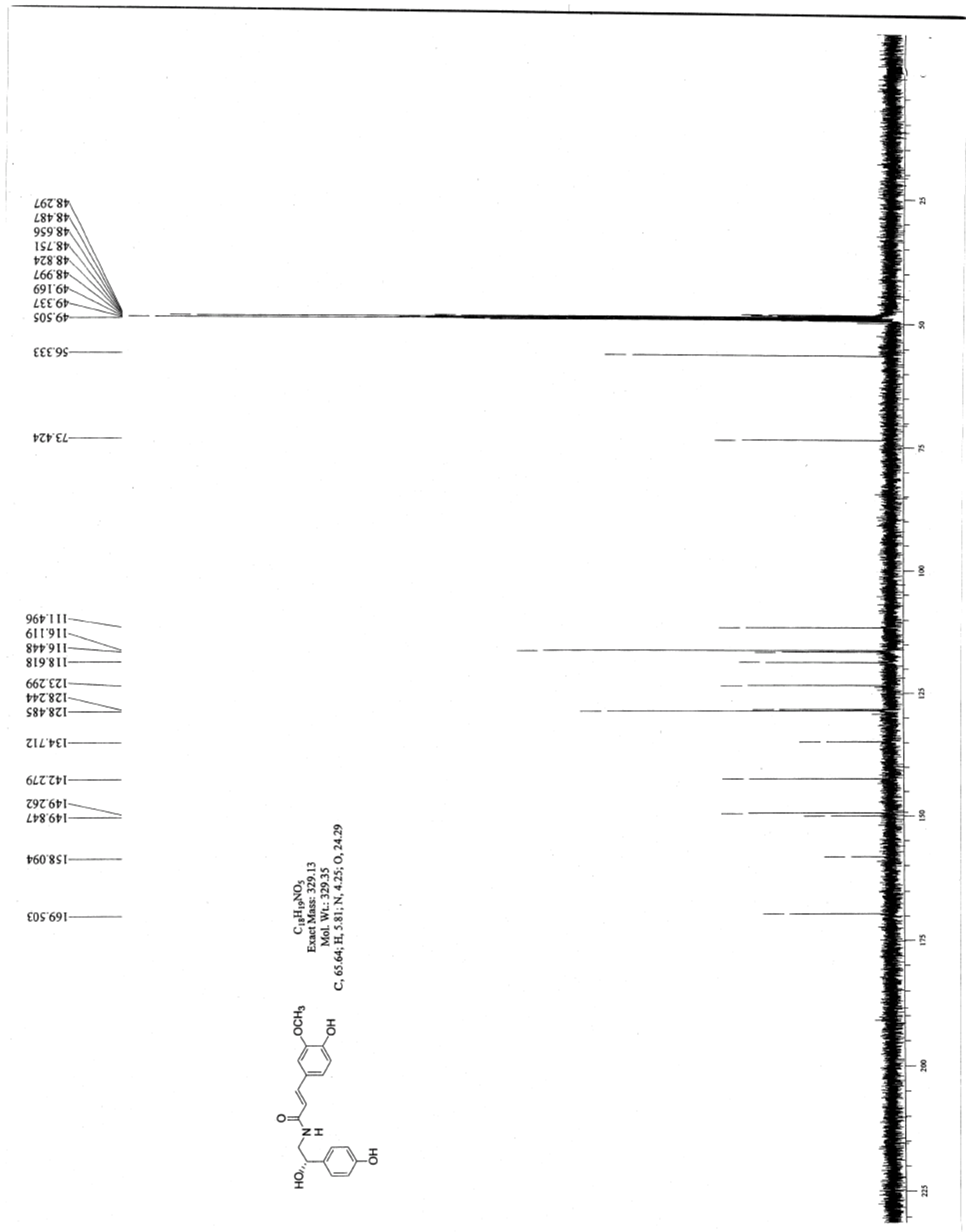




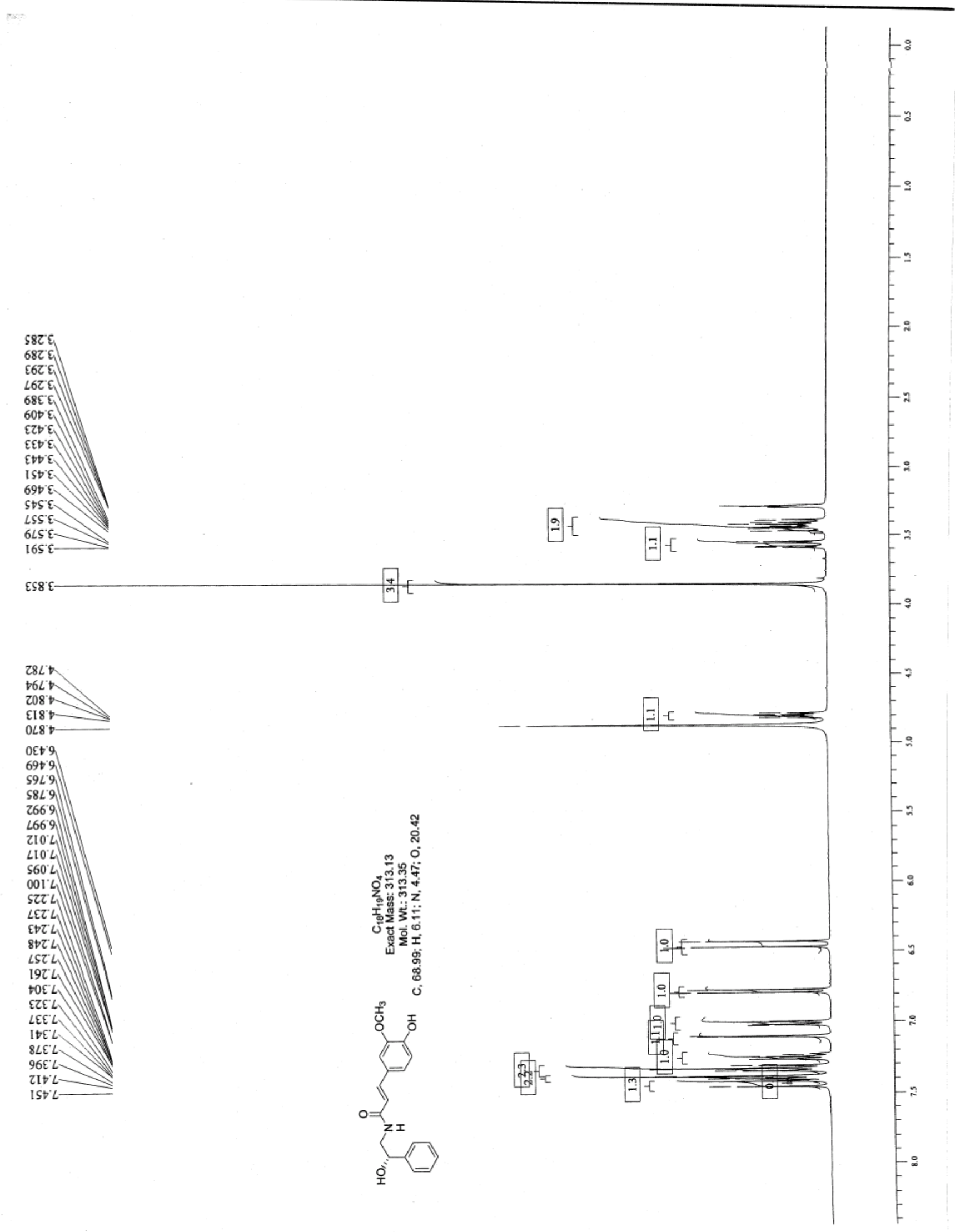




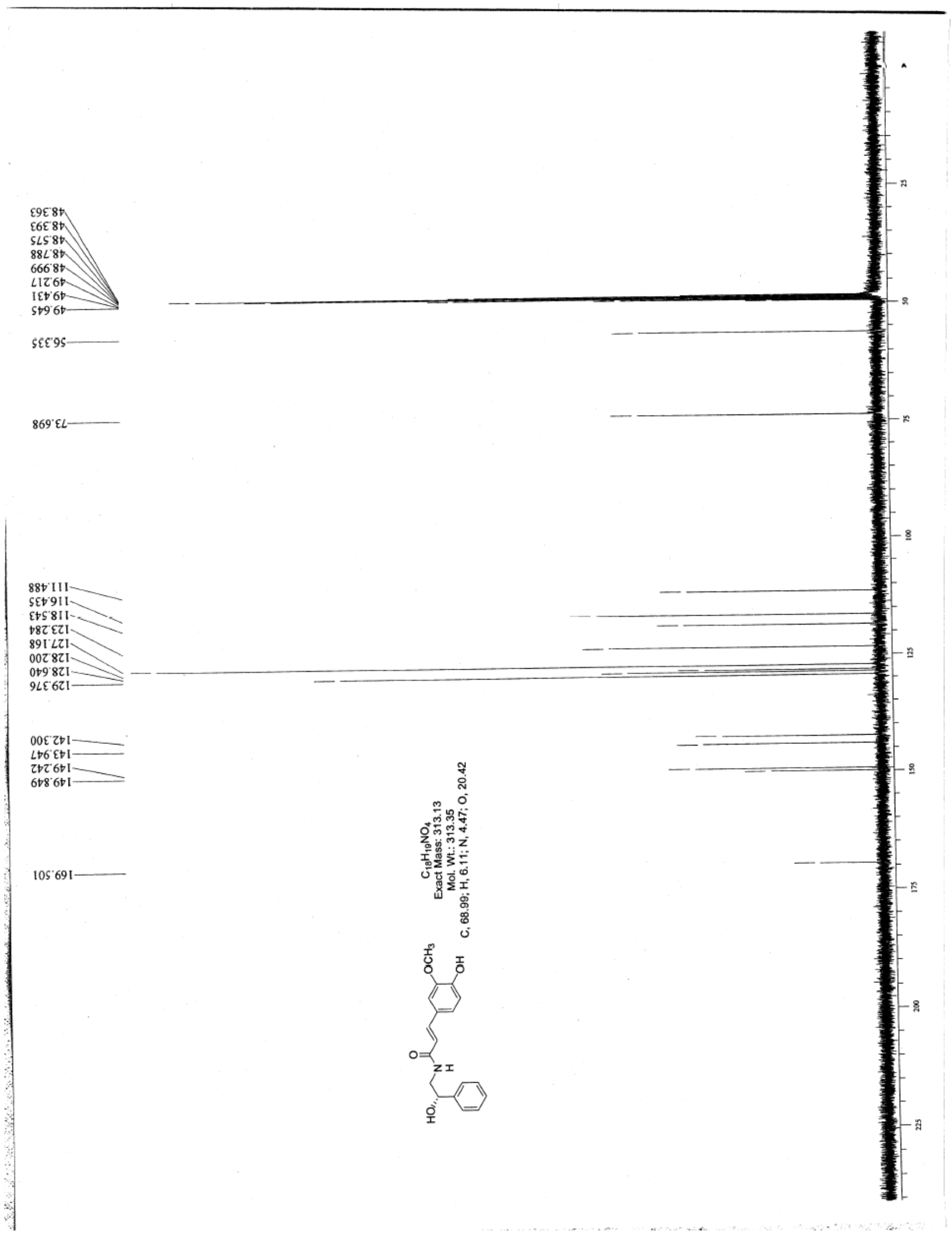




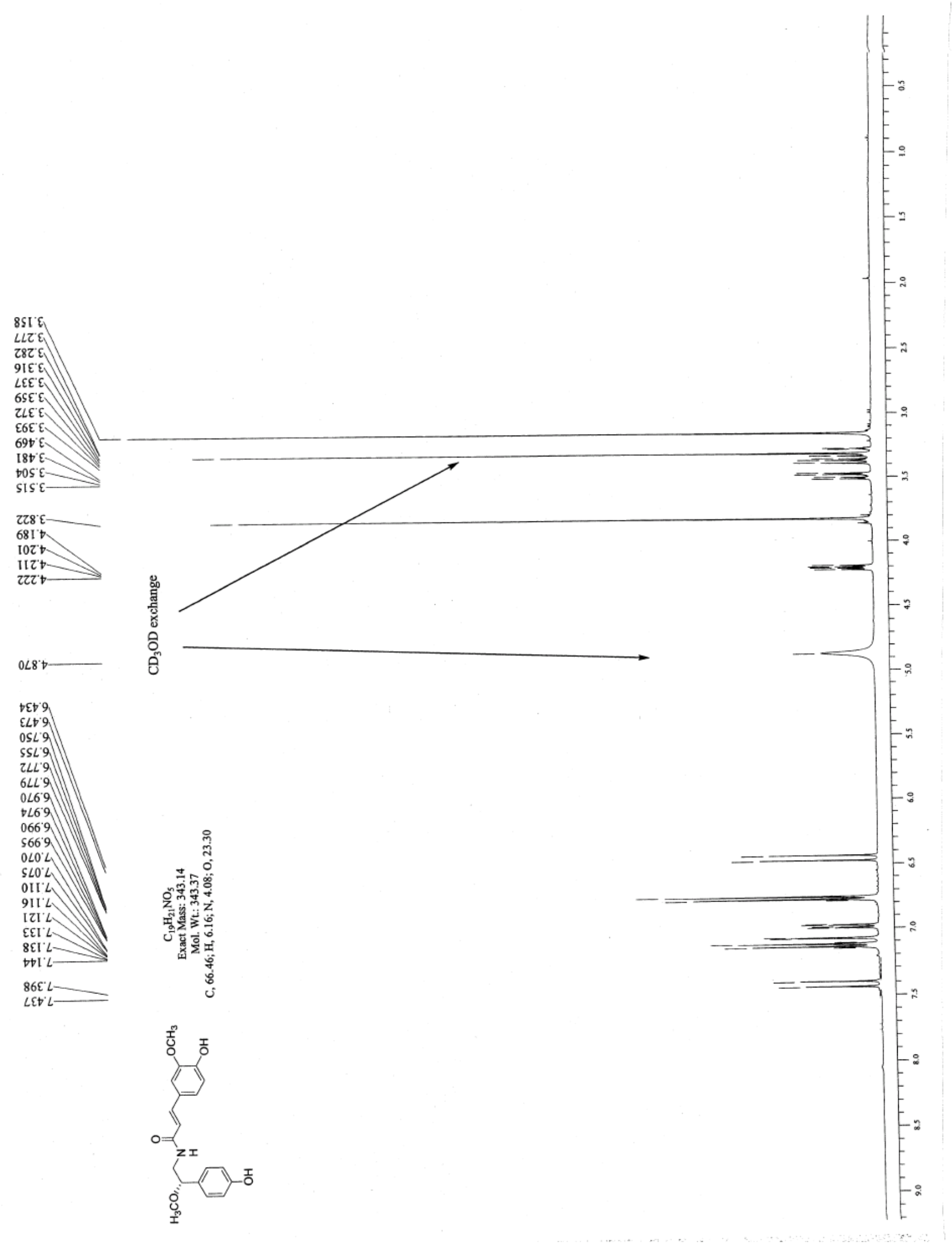




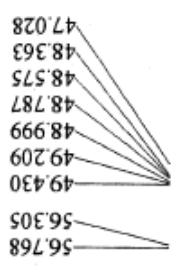

812 ع8 -

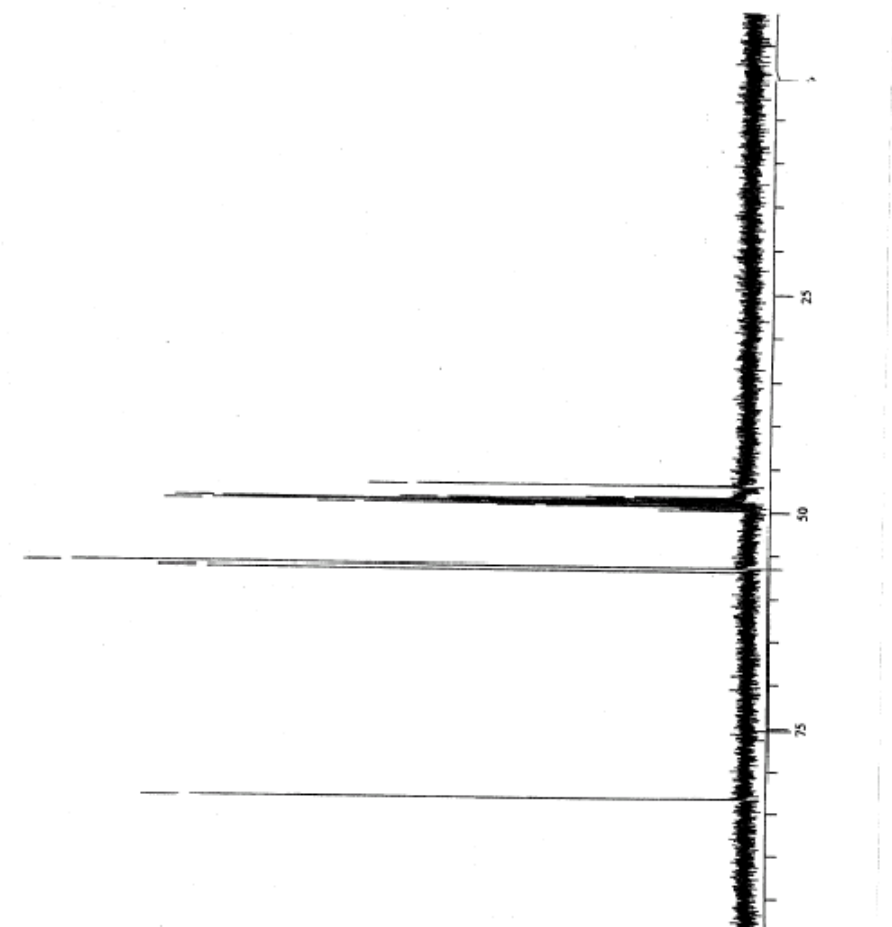

6It'III-

toE' 9 II -

$6 \mathrm{It} 9 \mathrm{II}$

t09.8 I I

$09 \tau \approx z 1$

$\angle 0 Z$ ' $\mathrm{ZI}$

$98 \mathrm{I} 6 \mathrm{ZI}$

SऽE' IE

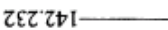

t0z 6 t

$\varepsilon L L^{\prime} 6 \mathrm{bl}-$

$\varepsilon L t \cdot 8 S I-$

tSI' 69 I-

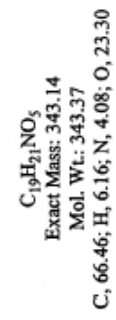

กิ

คें ले के

i.

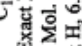

ن

$-8$

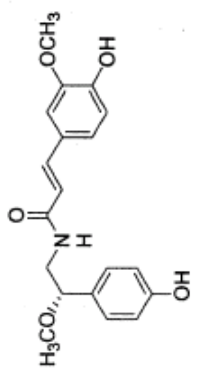

